\title{
PENNSYLVANIAN HETEROCONCHIA (MOLLUSCA, BIVALVIA) FROM THE PIAUÍ FORMATION, PARNAÍBA BASIN, BRAZIL
}

\author{
LUIZ EDUARDO ANELLI, ANTONIO CARLOS ROCHA-CAMPOS \\ Instituto de Geociências, USP, Rua do Lago, 562, 05508-080, São Paulo, SP, Brasil.anelli@usp.br, acrcampo@usp.br \\ MARCELLO GUIMARÃES SIMÕES \\ Instituto de Biociências, UNESP, Cx. P. 510, 18618-000, Botucatu, SP, Brasil.btsimoes@ibb.unesp.br
}

ROBERT L. PECK

HC 74 Box 98-G, Hinton, WV 25951-9115, USA.fossilpecker@netscape.net

\begin{abstract}
Dolostones of the upper Piauí Formation, Parnaíba Basin, Northern Brazil, record a rich and diversified invertebrate fauna of the Middle Pennsylvanian (Morrowan to Desmoinesian) age. Among bivalves, Heteroconchia is the most diversified (seventeen species) followed by Pteriomorphia (eleven species) and Palaeotaxodonta (three species). Heteroconch bivalves are found in parautochthonous to autochthonous fossil concentrations, some in storm (obrution) beds (Mucambo dolostones), showing disharmonious time-averaging. Among the species described [Pleurophorella? sp.; Schizodus alpinus (Hall, 1858); S. acuminatus Hoare, Sturgeon \& Kindt, 1978; S. ulrichi, Worthen, 1890; S. cf. wyomingensis Newell \& Boyd, 1975; Astartella subquadrata Lee \& Girty, 1909; Astartella cf. concentrica (Conrad, 1842); Wilkingia terminalis (Hall, 1852); Sanguinolites sp. 1; Sanguinolites sp. 2; Exochorhynchus sp.; cf. Anomalodesmata indet. 1 and Anomalodesmata indet. 2], three are new (Pleurophorella parnaibaensis n. sp.; Chaenomya caatingaensis n. sp.; Exochorhynchus buriti n. sp.). In addition, the genus Carnauba (Megadesmidae) is proposed and represented by a single species, $C$. oiticica n. gen. and n. sp. The internal diagnostic features of some species, especially those belonging to Schizodus, are reported here for the first time. Finally, the bivalves studied show affinities to species of the Amazon basin (Itaituba Formation), and the Carboniferous of North America. reinforcing a Middle Pennsylvanian age for the fauna.
\end{abstract}

Key words: Heteroconchia, Mollusca, Pennsylvanian, Piauí Formation, Brazil.

RESUMO - Dolomitos da parte superior da Formação Piauí, bacia do Parnaíba, Brasil, preservam uma fauna rica e diversificada de invertebrados de idade Pensilvaniano Médio (Morrowano até Desmoinesiano). Dentre os bivalves, Heteroconchia é o grupo mais diversificado (dezessete espécies), seguido por Pteriomorphia (onze espécies) e Palaeotaxodonta (três espécies). Os Heteroconchia aqui estudados ocorrem em concentrações fossilíferas parautóctones a autóctones, algumas em depósitos de sufocamento ou tempestitos distais, mostrando mistura temporal desarmoniosa. Dentre as espécies descritas [Pleurophorella? sp.; Schizodus alpinus (Hall); S. acuminatus Hoare, Sturgeon \& Kindt; S. ulrichi Worthen; Schizodus cf. wyomingensis Newell \& Boyd; Astartella subquadrata Lee \& Girty; Astartella cf. concentrica (Conrad); Wilkingia terminalis (Hall); Sanguinolites sp. 1; Sanguinolites sp. 2; Exochorhynchus sp.; cf. Anomalodesmata indet. 1 e Anomalodesmata indet. 2] três são novas (Pleurophorella parnaibaensis n. sp.; Chaenomya caatingaensis n. sp.; Exochorhynchus buriti n. sp.). Adicionalmente, um novo gênero, Carnauba (Megadesmidae), é proposto, sendo representado por espécie única, C. oiticica n. gen. and n. sp. As feições anatômicas internas, diagnósticas de várias espécies, especialmente de Schizodus são descritas pela primeira vez. Finalmente, os bivalves estudados têm afinidades com formas coevas da bacia do Amazonas (Formação Itaituba) e do Carbonífero da América do Norte, reforçando a atribuição de idade Pensilvaniano Médio para a fauna.

Palavras-chave: Heteroconchia, Mollusca, Pensilvaniano, Formação Piauí, Brasil.

\section{INTRODUCTION}

The Piauí Formation contains the most diverse fossil record of bivalves known from the Upper Paleozoic rocks of South America. The material comes from beds of Pennsylvanian (Morrowan-Atokan to early Desmoinesian age, Campanha and Rocha-Campos, 1979) exposed at the northeastern part of the Parnaíba Basin (Figure 1A). Dolostones cropping out near the José de Freitas village, named Mucambo, Esperança, Meruóca, and Contendas dolostones (Figures 1B-F), are associated with sandstones, siltstones, and mudstones deposited on a shallow-marine carbonate shelf (Lima Filho, 1991, 1999). They preserve a rich and varied, bivalve-dominated fauna (Anelli, 1999; Anelli et 
al., 2002, 2006). The fauna also includes many gastropods and cephalopods, and some brachiopods and bryozoans. Trilobites are less common (Anelli, 1999).

Until 2000, previous authors had described and illustrated only two macroinvertebrate species of the Piauí Formation fauna, including the trilobite Phillipsia (Ameura) plummeri (Kegel, 1951), and the bivalve Heteropecten trichotomus (Kegel \& Costa, 1952). More recently, Anelli et al. (2002, 2006, and this contribution) have provided the description of 30 bivalve species. However, work in progress, including the crassatelloidean bivalves suggests that the fauna is even more diversified. In this contribution the taxonomic description of members of the Heteroconchia Hertwig, 1895 is presented and discussed. Preliminary
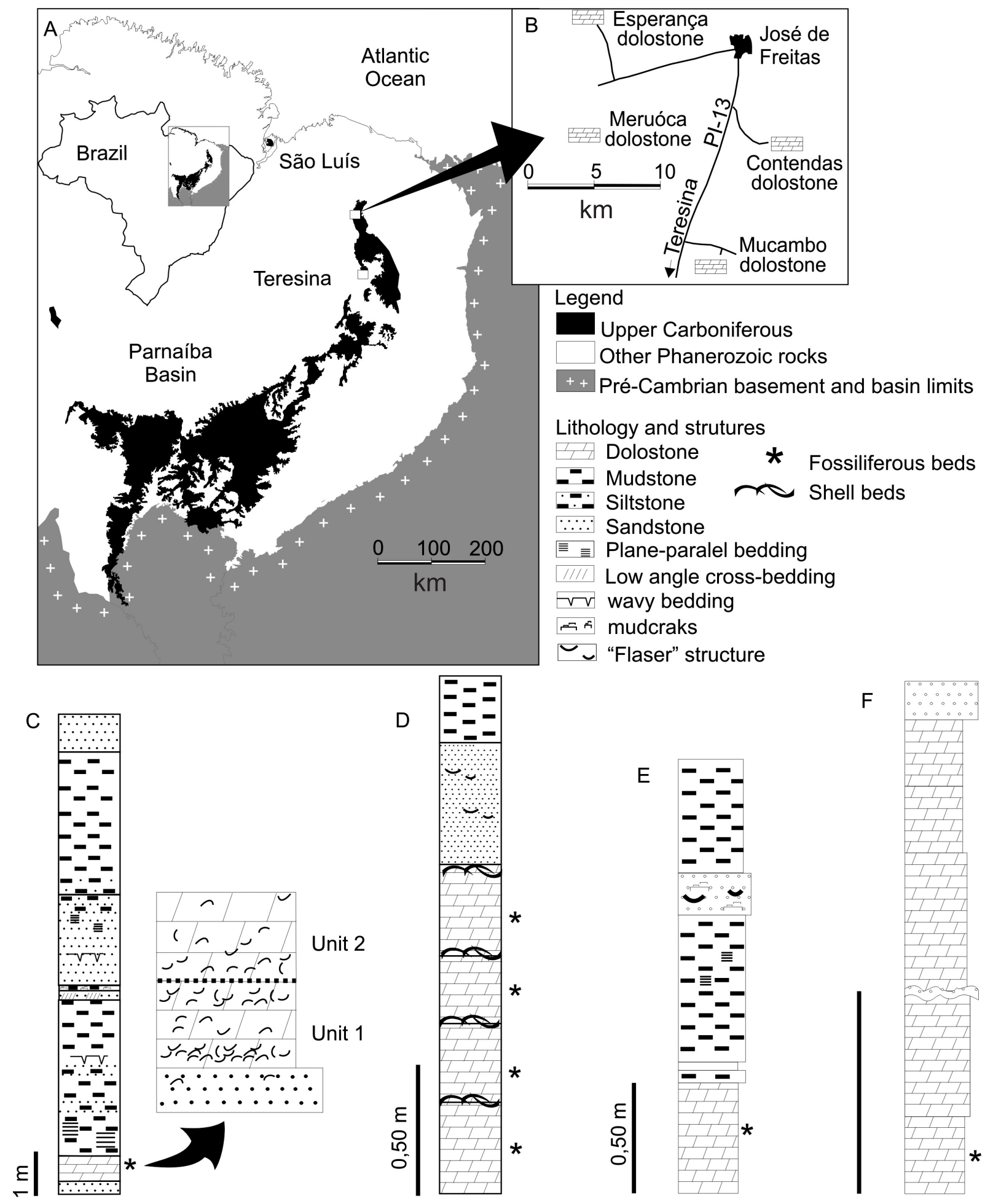

Figure 1. A, Structural map showing the Piauí Formation (black) in the Parnaíba Basin, northeastern Brazil; B, outcrops of Mucambo, Esperança, Contendas and Meruóca dolostones; C-F, stratigraphic sections showing the Mucambo, Esperança, Contendas and Meruóca dolostones. 
comments on the taphonomy and paleoecology of the studied species are also provided.

\section{MATERIAL AND METHODS}

For this study, a total of two hundred and fifty specimens of heteroconch bivalves were examined. The specimens come from the walls of abandoned or in operation dolostone quarries of the Piauí Formation around the village of José de Freitas, Piauí (Figure 1B). In the study area, several dolomitic facies each varying in thickness from 1 to $2 \mathrm{~m}$ characterize the upper part of the formation ( $15 \mathrm{~m}$ thick). The beds were deposited during transgressive conditions, when a large carbonate and evaporite platform developed (Lima Filho, 1991, 1999).

The specimens were collected and prepared according to standard paleontological techniques (Feldmann et al., 1989) and are housed in the scientific collection of the Instituto de Geociências, Universidade de São Paulo, under the code GP/ 1E. In addition, several specimens belonging to the Departamento Nacional da Produção Mineral (DNPM), Rio de Janeiro, were also analyzed and described.

The suprageneric systematics is based on Amler (1999) for the pteriomorphians, and on Morris et al. (1991) for the anomalodesmatans. The elongation and obesity indexes are described according to Stanley (1970), but caution must be taken when considering those values, since some specimens (Chaenomya caatingaensis and Wilkingia terminalis) may be compressed along the main shell axis. The bivalves are preserved as internal and external molds. Internal characteristics including muscle scars are described for various specimens.

Anatomical abbreviations. aa, anterior adductor; abr, anterior byssal retractor; app, anterior pedal protractor; $\mathbf{c m}$, crenulated margin; pa, posterior adductor; pl, pallial line; ppr, posterior pedal retractor; ps, pallial sinus; ue, umbonal elevator.

\section{SYSTEMATIC PALEONTOLOGY}

\author{
Subclass HETEROCONCHIA Hertwig, 1895 \\ Superorder PALAEOHETERODONTA Newell, 1965 \\ Order MODIOMORPHOIDA Newell, 1969 \\ Superfamily KALENTEROIDEA Marwick, 1953 \\ Family PERMOPHORIDAE van de Poel, 1959 \\ Subfamily PERMOPHORINAE van de Poel, 1959 \\ Pleurophorella Girty, 1904
}

Type species. Pleurophorella papillosa Girty, 1904, by original designation.

Diagnosis. As in Morris et al. (1991).

Discussion. Carboniferous permophorids from several localities (e.g., Morningstar, 1922; Hoare et al., 1979; Benedetto, 1980a), which are very similar to the specimens from the Piauí Formation, were assigned to the genus Permophorus Chavan, 1954 even though these specimens did not exhibit internal diagnostic features. The majority of the diagnoses provided for the genus Permophorus (Chavan, 1954, 1969; Logan, 1967; Newell \& Boyd, 1999) focus on the existence of one cardinal tooth in each valve. The studied specimens from the Piauí Formation yield all the diagnostic characters presented by Newell \& Boyd (1999) for Permophorus, except for the cardinal tooth. This character is definitely absent in the numerous internal molds studied, even in those specimens with well-preserved hinge areas.

Girty (1904: 728) erected Pleurophorella from the Carboniferous of Texas. The diagnostic features include a commissure line which is completely closed, indicating an absence of gapes; the granulose surface, with the papillae tending to an arrangement in radial lines; and the presence of an umbonal costa delineating a truncated posterior end. Cox et al. (1969) diagnosed Pleurophorella as "externally like Permophorus but somewhat less inequilateral, thin, ornamented only by minute papillae and weak concentric lines; lunule and escutcheon sharply defined. Interior unknown." Morris et al. (1991: 84) emended the diagnosis, greatly increasing it with external and new internal features, as follows: "transversely elongate, distinct lunule and escutcheon, radiating ornament fairly well developed, especially in posterior part of shell. Granulation of shell surface by periostracal spicules distinct, apparently absent in some. More or less edentulous. Ligament lodged in a narrow elongated groove in the anterior part of a flat escutcheon which extends well towards the rear. Nymphs slender and low. The anterior adductor scar is well differentiated and bounded at the rear by a distinct buttress". The material from the Piauí Formation is being assigned to the genus Pleurophorella because of the presence of the radial costae at the posterior part of shell, the absence of cardinal teeth, and the presence of a well marked anterior adductor scar bounded posteriorly by a buttress.

\section{Pleurophorella parnaibaensis $\mathrm{n}$. $\mathrm{sp}$. (Figures 2A-G, Table 1)}

Diagnosis. Pleurophorella shell with a reduced anterior lobe, ventral and dorsal margins that are subparallel, and no umbonal carina defining the truncated posterior margin.

Etymology. Parnaiba, after the name of the great river Parnaiba that defines the western border of Piauí State.

Holotype. DNPM 264a, an internal mold of left valve.

Paratypes. DNPM 079, 080, 083, 089, 092, 104, 161, 204, 233, 238, 261, 264a, 264b; GP/1T 1990, 1991, 2225.

Material. Eleven internal molds and six external molds of disarticulated left and right valves.

Locality and horizon. José de Freitas, Piauí State, Brazil; Piauí Formation, Mucambo and Meruóca dolostones.

Age. Middle Pennsylvanian.

Description. Shell sub-rectangular, higher at posterior extremity; equivalve, very inequilateral, very elongated posteriorly; inflated. Umbones depressed, close to anterior extremity; beaks prosogyrous. Dorsal and ventral margins subparallel; anterodorsal margin greatly reduced; anterior extremity greatly reduced and rounded; ventral margin almost straight, with large but shallow sulcus close to midlength; posterior extremity higher than anterior, rounded; 
posterodorsal margin straight. Lunule short, well marked; escutcheon elongated. Surface ornament of well-marked, irregularly spaced comarginal growth lines; four to five faintly marked radial ribs on posterior region. Cardinal teeth absent. Single well developed, elongated lateral tooth from mid-length of shell to posterior end of dorsal margin of left valve; corresponding socket present in right valve. Anterior adductor muscle scar large, ovoid, located on anterior extremity. Small byssal retractor scar present above anterior adductor muscle scar. Prominent buttress present behind both scars. Posterior adductor scar not observed. Pallial line well marked on the anterior portion.

Discussion. In North America, comparable material has been assigned to Permophorus and Pleurophorella (Girty, 1903; Morningstar, 1922; Winters, 1963; Gordon \& Pojeta, 1975; Brew \& Beus, 1976; Hoare, 1993) as well as to Sphenotus (Busanus \& Hoare, 1991; Hoare, 1993), including descriptions of cardinal teeth. Pleurophorus spinulosa (Morningstar, 1922) and Pleurophorus subcostatus (Meek \& Worthen, 1866) are species with greatly reduced anterior areas and with three to four radial ridges in the posterior region, similar to the specimens from the Piauí Formation, but with no hinge features described. Since the internal features of those specimens are unknown, their assignment to Pleurophorus is uncertain.

In South America, two Pennsylvanian species from the Amazon Basin, Pleurophorus brasiliensis (Duarte, 1938; Mendes, 1966) from the Itaituba Formation and Permophorus sp. from the Caño Indio Formation of Venezuela (Benedetto, 1980a), have a similar profile but do not have internal features described. Similar material assigned to Pleurophorella? has been found in the Carboniferous (González, 1997) and Permian (Sterren, 2004) strata of Argentina, but in both cases the internal features are too poorly preserved for rigorous comparison.

Pleurophorella parnaibaensis n. sp. from the Piauí Formation differs from all South American species by its

Table 1. Measurements $(\mathrm{mm})$ of Pleurophorella parnaibaensis $\mathrm{n}$. $\mathrm{sp}$. Asterisks indicate incomplete valves.

\begin{tabular}{l|cccccc} 
specimen & valve & length & height & width & elongation & obesity \\
\hline DNPM 264b & $\mathrm{L}$ & 25 & 8 & 6 & 3.0 & 1.35 \\
DNPM 261 & $\mathrm{L}$ & $24^{\star}$ & 1 & - & 2.4 & - \\
DNPM 079 & $\mathrm{R}$ & 20 & 9 & 4 & 2.22 & 1.12 \\
DNPM 204 & $\mathrm{R}$ & 20 & 8 & 6 & 2,5 & 1,33 \\
DNPM 233 & $\mathrm{R}$ & $17^{\star}$ & $7^{\star}$ & - & 2.4 & - \\
DNPM 238 & $\mathrm{R}$ & - & 9.1 & 3.9 & - & 1.16 \\
DNPM 083 & $\mathrm{L}$ & 16.6 & - & 2.4 & - & - \\
DNPM 264a & $\mathrm{L}$ & 14 & 7 & 2.1 & 2.00 & 1.66 \\
GP/1T 1990 & $\mathrm{R}$ & 14 & 6 & 2.9 & 2.33 & 1.03 \\
DNPM 089 & $\mathrm{R}$ & 13 & 6 & 2.9 & 2.14 & 1.05 \\
DNPM 080 & $\mathrm{L}$ & 13 & 7 & 3 & 1.83 & 1.18 \\
DNPM 161 & $\mathrm{R}$ & 12 & 6 & - & 2.1 & - \\
GP/1T 1991 & $\mathrm{L}$ & 8 & 4 & 2.1 & 1.97 & 0.97 \\
\hline
\end{tabular}

greatly reduced anterior portion, subparallel dorsal and ventral margins and by the absence of costae defining a truncated posterior margin.

\section{Pleurophorella? sp. \\ (Figures 2H-I)}

Material. One internal mold of left valve. GP/1T 2029.

Locality and horizon. José de Freitas, Piauí State, Brazil; Piauí Formation, Meruóca dolostone.

Age. Middle Pennsylvanian.

Description. Internal mold of left valve subrectangular, inequilateral (length, $44 \mathrm{~mm}$; height $19 \mathrm{~mm}$ ), and very elongated posteriorly (elongation index 2.3). Umbone located close to anterior extremity; umbonal carina weakly marked.

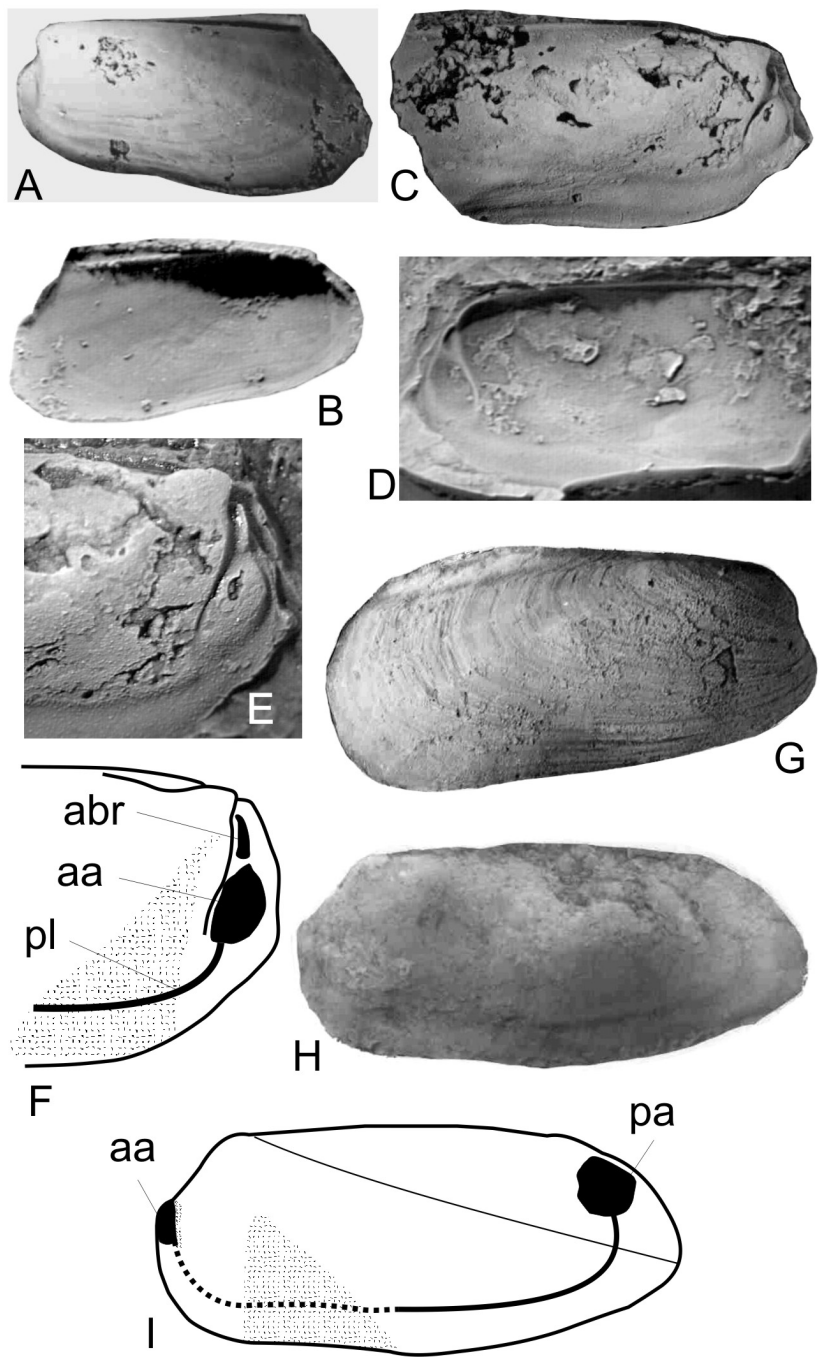

Figure 2. A-G, Pleurophorella parnaibaensis n. sp., Mucambo dolostone: A, holotype, DNPM 264a, internal mold of left valve, x2.5; B, latex cast, internal view of left side, same specimen, x2.5; C, DNPM 238 , fragment of a internal mold, right view, $x 2.5$; $\mathbf{D}$, latex cast of the same specimen, x2.5; E, magnified view of hinge features and muscle scars on the anterior region of the internal mold, same specimen, $x 3$; F, muscle scar based on specimen DNPM 238, x3; G. DNPM 204, latex cast, external view of right side, x2.5. H-I, Pleurophorella? sp., Meruóca dolostone: H, GP/1T 2029, internal mold of left valve, x1.2; I, muscle scar based on the same specimen, $x 1.2$. 
Ventral margin with gentle inflexion from shallow sinus; postumbonal ridge rounded but well-defined. Dorsal and ventral margins parallel. Anterodorsal margin reduced; anterior extremity rounded, ventral margin moderately convex; posterior extremity truncated. Anterior adductor muscle scar small, posterior adductor muscle scar circular, positioned close to posterodorsal angle. Pallial line thick, visible only on posterior portion of the internal mold.

Discussion. Pleurophorella? sp. is a single, poorly preserved internal mold with distinct, rounded posterior umbonal ridge defining a truncated posterior margin, and absence of cardinal teeth, suggesting the genus Pleurophorella Girty, 1904. P. geinitzi (Meek, 1872) from the Carboniferous Conemaugh Formation (Morningstar, 1922) is a very close match in general shape but differs by the well defined radial ribs in the posterior portion of shell. Pleurophorella? sp. described by González (1997) from the Carboniferous of western Argentina differs by its well defined radial ribs, costae, and more rectangular profile. Pleurophorella ? sp. described by Sterren (2005) from the Carboniferous La Capilla Formation of Argentina is more rectangular in profile.

Order TRIGONIOIDA Dall, 1889

Superfamily TRIGONIOIDEA Lamarck, 1819

Family SCHIZODIDAE Newell and Boyd, 1975

Schizodus de Verneuil \& Murchison, 1844

Type-species. Axinus obscurus J. Sowerby, 1821. Subsequent designation by de Verneuil, 1845.

Comments. Newell \& Boyd (1975: 95-96) presented a revised diagnosis for Schizodus. All specimens from the Piauí Formation bear similar outline and dental formula for Schizodidae.

\author{
Schizodus alpinus (Hall, 1858) \\ (Figures 3A-D, Table 2)
}

Material. 29 internal molds: DNPM 070, 154, 162, 168, 169, 211, 136, 217, 195, 212a.; GP/1T 1984, 1985, 1986, 1987, 1988, $1989,2226,2227,2228,2229,2230,2231,2232,2233,2234,2235$, 2236, 2237, 2238.

Locality and horizon. José de Freitas, Piauí State, Brazil; Piauí Formation, Mucambo dolostone.

Age. Middle Pennsylvanian.

Description. Length of internal mold slightly greater than height, subtrigonal in shape, slightly inequilateral, equivalve, slightly elongated; moderately inflated. Umbones inflated, above hinge line; beaks orthogyrous to slightly prosogyrous. Anterior umbonal flank not sharply differentiated; postumbonal ridge rounded. Anterodorsal margin continuous with rounded, expanded anterior extremity; ventral margin convex; posterior extremity obliquely truncated, defining large respiratory margin; posterodorsal margin oblique, straight. Lunule, escutcheon absent. External features unknown. Hinge very short. Cardinal pivotal teeth cuneiform, with triangular base, shallow sulcus facing ventral margins. Second elongated cardinal tooth, smaller than pivotal, posterior to pivotal tooth in right valve, anterior to pivotal tooth in left valve. Teeth size, shape vary slightly. Lateral teeth absent. Nymph very faint, elongated. Adductor muscles scars isomyarian, subcircular, near antero- and posterodorsal angles. Anterior and posterior pedal retractor muscles scars elongated, connected to adductor scars; well-developed umbonal elevator muscle scar present on extremity of umbones. Pallial line faintly marked.

Discussion. Newell \& Boyd (1975) called attention to the long ranging $S$. alpinus reported in several localities of the Pennsylvanian System in the United States; however, the internal diagnostic characters for numerous Mississippian and Pennsylvanian specimens of S. alpinus had not been observed. Internal diagnostic characters for S. alpinus including descriptions of the adductor and pedal muscle and pallial line scars not reported by Newell \& Boyd (1975) are provided here for the first time.

Two Paleozoic species of Schizodus have been described from Brazil: Schizodus amazonicus Mendes, 1966 from the Pennsylvanian Itaituba Formation of the Amazon Basin, which is a poorly preserved fragmented specimen without muscle scars or hinge features; and Schizodus occidentalis Reed, 1930 from the Paraná Basin, later revised by Rocha-Campos (1970). Both species differ from S. alpinus, the latter having the presence of an elongated posterior lateral tooth in the left valve, a posterior pedal retractor muscle scar positioned immediately above the posterior adductor scar, and a more compressed shell. Another species from South America was recognized by González (1969), Schizodus sp., from the late Paleozoic of Argentina. It differs from S. alpinus by the presence of a well-marked buttress posterior to the anterior adductor scar.

Several species from the Carboniferous of North America, S. affinis Herrick, 1887 (Hoare et al., 1979), S. chesterensis Meek and Worthen, 1860 (Hoare et al., 1989), and S. depressus (Hoare, 1993), are similar in general shape but have no internal features described.

Table 2. Measurements $(\mathrm{mm})$ of Schizodus alpinus. Asterisks indicate incomplete valves.

\begin{tabular}{l|cccccc} 
specimen & valve & length & height & width & elongation & obesity \\
\hline DNPM 162 & $\mathrm{L}$ & 27 & 22 & 8 & 1.20 & 1.4 \\
DNPM 169 & $\mathrm{R}$ & 27 & 21 & 8 & 1.38 & 1.3 \\
GP/1T 1985 & $\mathrm{R}$ & 26 & 22 & 12 & 1.18 & 1.8 \\
DNPM 211 & $\mathrm{L}$ & 24 & 20 & 7 & 1.2 & 1.4 \\
GP/1T 1986 & $\mathrm{R}$ & 24 & 21 & 14 & 1.14 & 1.5 \\
DNPM 136 & $\mathrm{R}$ & 23 & 19 & 7 & 1.19 & 1.4 \\
DNPM 217 & $\mathrm{L}$ & 23 & 19 & 6 & 1.18 & 1.6 \\
DNPM 195 & $\mathrm{L}$ & 21 & 18 & 5 & 1.17 & 1.8 \\
GP/1T 1987 & $\mathrm{L}$ & 20 & 17 & 12 & 1.17 & 1.4 \\
GP/1T1984 & $\mathrm{R}$ & - & 12 & 6 & - & 2.0 \\
GP/1T 1988 & $\mathrm{L}$ & 13 & 11 & 7 & 1.18 & 1.5 \\
DNPM 212a & $\mathrm{R}$ & 11 & 10 & 2 & 1.10 & 2.0 \\
\hline
\end{tabular}


Schizodus acuminatus Hoare, Sturgeon \& Kindt, 1978 (Figures 3E-J, Table 3)

Material. Six internal molds of left (3) and right (3) valves: GP/1T 1977, 1979, 1982, 1983, 1984, 2030.

Locality and horizon. José de Freitas, Piauí State, Brazil; Piauí Formation, Mucambo dolostone.

Age. Middle Pennsylvanian.

Description. Shell strongly inequilateral, equivalve; moderately elongate, inflated to moderately inflated. Umbones prominent, projected well above hinge line. Beaks orthogyrous to slightly prosogyrous. Postumbonal ridge well-defined, slightly concave. Anterodorsal margin continuous with short anterior margin; ventral margin convex; posterior extremity obliquely truncated, defining respiratory margin slightly greater than half height; posterodorsal margin straight. Lunule, escutcheon absent. External features of shell absent. Left hinge with large, cardinal, triangular, pivotal tooth separated from anterior smaller tooth by large. Socket for elongated posterior tooth of right valve above principal cardinal tooth of left valve. Elongated nymph above left socket. Lateral teeth absent. Adductor muscles scars well-marked, close to antero- and posterodorsal angles; anterior adductor scar subcircular; posterior adductor scar with constriction in mid portion. Anterior retractor muscle scar elongated, connected to adductor scar; posterior retractor scar small, not connected to adductor scar. Well developed umbonal elevator scar present on extremity of beak. Pallial line well marked.

Discussion. Schizodus acuminatus Hoare et al., 1978 was erected to describe schizodids from Pennsylvanian rocks in West Virginia. These authors pointed out the similarities in shape to $S$. cuneatus Meek, 1875 recognized by Girty (1903) in rocks from the Permian Rico Formation in Colorado, and also by Morningstar (1922) from the Pottsville fauna in Ohio, differing only by the more strongly truncated posterior ventral angle of the respiratory margin in S. acuminatus.

S. texanus Clifton, 1942 from the Permian Leonard Series, also recognized by Chronic (1952) from the Permian Kaibab Formation of North America and illustrated by Newell and Boyd (1975: 118, fig. 53), resemble S. acuminatus in tooth outline of the right valve. However, $S$. texanus differs from $S$. acuminatus by its more developed anterior region, greater umbonal angle, and reduced respiratory margin which is smaller than the half of its height.

Table 3. Measurements $(\mathrm{mm})$ of Schizodus acuminatus. Asterisks indicate incomplete valves.

\begin{tabular}{l|cccccc} 
specimen & \multicolumn{1}{|c}{ valve } & length & height & width & elongation & obesity \\
\hline GP/1T 1979 & R & 41 & 33 & 24 & 1.24 & 1.37 \\
GP/1T 1984 & L & 32 & 26 & 16 & 1.23 & 1.62 \\
GP/1T 1977 & L & 29 & 24 & 18 & 1.20 & 1.33 \\
GP/1T 1982 & R & $29^{\star}$ & 28 & 17 & - & 1.64 \\
GP/1T 1983 & L & $26^{\star}$ & 27 & 18 & - & 1.50 \\
GP/1T 2030 & R & 22 & 18 & 12 & $?$ & $?$ \\
\hline
\end{tabular}
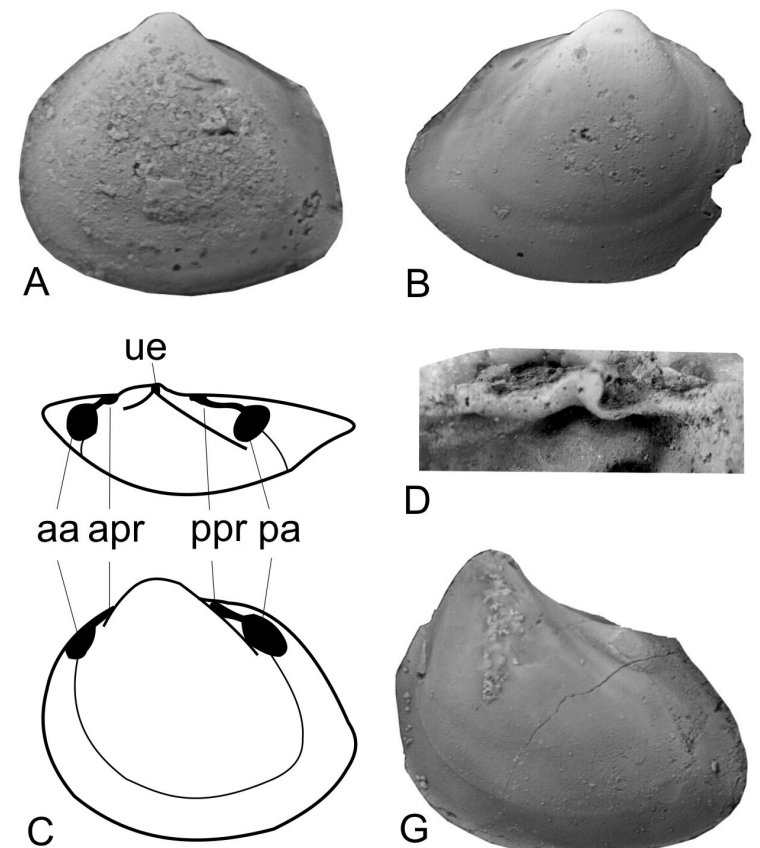

D
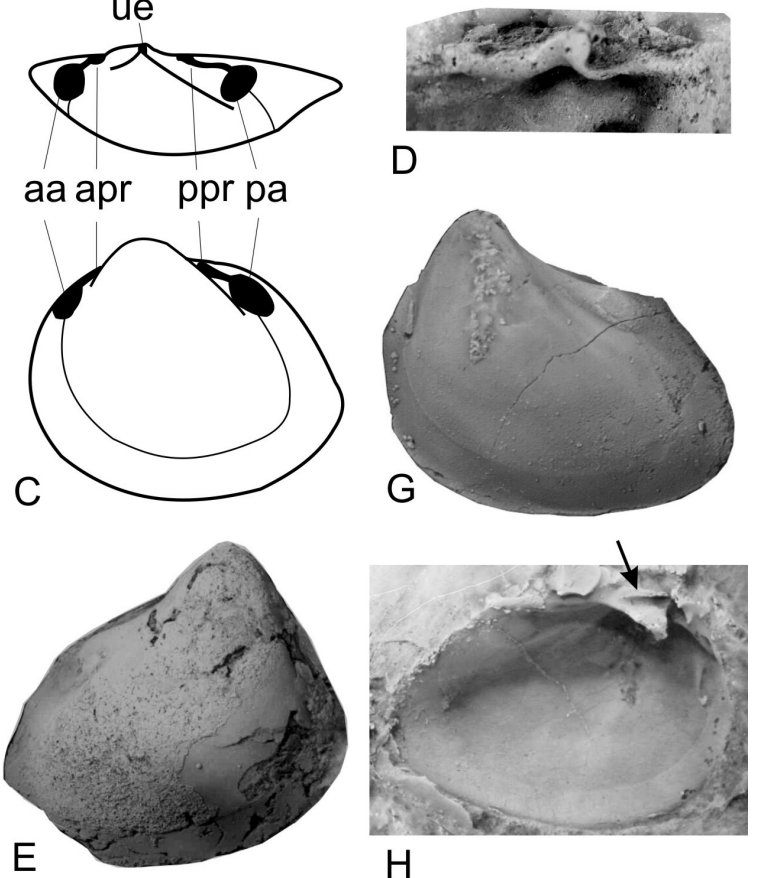

$\mathrm{H}$
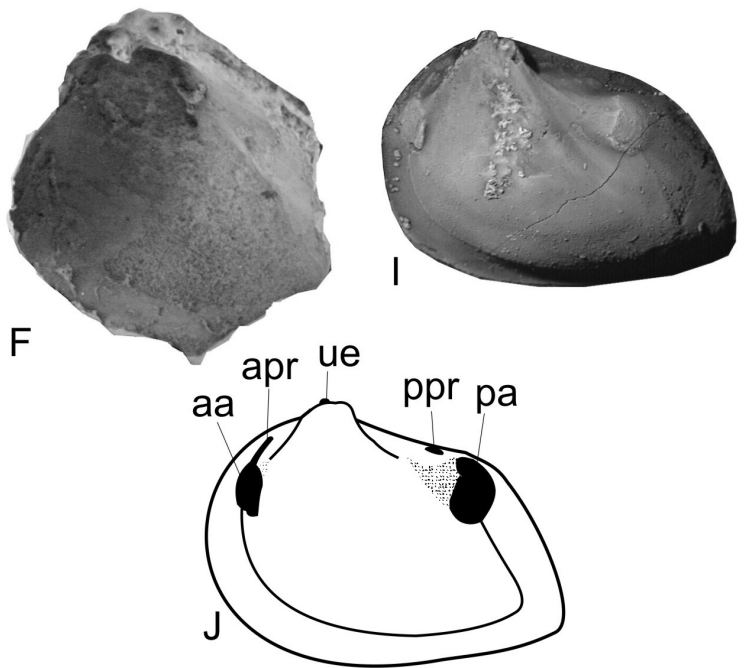

Figure 3. A-D, Schizodus alpinus (Hall, 1858), Mucambo dolostone: A, DNPM 195, internal mold of left valve, x1.5; B, GP/1T 1985, internal mold of right valve, x1.5; C, muscle scars based on specimen DNPM 070, dorsal and lateral view of a internal mold, left view, x1.5; D, GP/1T 1985, latex cast, internal view of the cardinal area showing pivotal tooth of right valve, x6. E-J, Schizodus acuminatus Hoare, Sturgeon and Kindt, 1978, Mucambo dolostone: E, GP/1T 1982, internal mold of right valve, x1.3; F, latex cast, internal view of right side showing hinge features, same specimen, x1.3; G, GP/1T 1977, internal mold of left valve, x1.3; H, latex cast, internal view of left side showing hinge features, arrow indicates nymph, same specimen, x1.3; I, GP/1T 1977, oblique dorsal view showing muscle scars situated on the dorsal area , x1,3; J, muscle scars based in the same specimen, left valve oblique view, x1.3. 
Schizodus ulrichi Worthen, 1890

(Figures 4A-G, Table 4)

Material. Three internal molds of right valves and one internal mold of conjugated valves. GP/1T 1978, 1980, 1981, 2220.

Locality and horizon. José de Freitas, Piauí State, Brazil; Piauí Formation, Mucambo dolostone.

Age. Middle Pennsylvanian.

Description. Shell strongly inequilateral, equivalve; moderately elongate to elongate, inflated to moderately

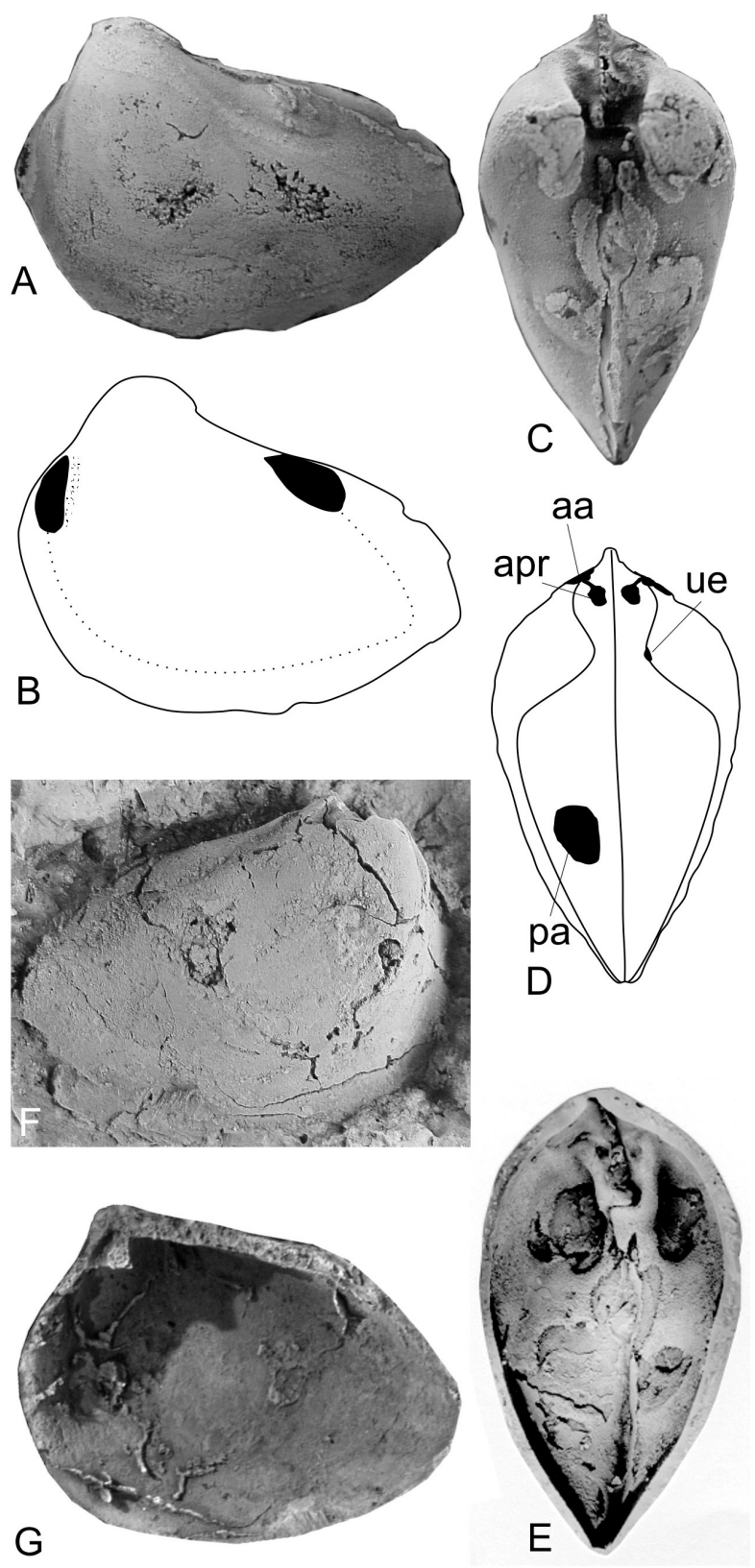

Figure 4. Schizodus ulrichi Worthen, 1890, Mucambo dolostone: A, GP/1T 1978, internal mold, left side view x1; B, muscle scars based in the same specimen, left side view, $\mathrm{x} 1$; $\mathbf{C}$, dorsal view of the same specimen, $x 1 ; \mathbf{D}$, muscle scars based on the same specimen, dorsal view, $x 1 ; \mathbf{E}$, latex cast, internal view showing hinge features, same specimen, x1; F, GP/1T 1981, internal mold, right side view, $x 1$; $G$, latex cast, internal view of a right side showing hinge features, same specimen, $x 1$.
Table 4. Measurements ( $\mathrm{mm}$ ) of Schizodus ulrichi. Asterisks indicate incomplete valves.

\begin{tabular}{l|cccccc} 
specimen & \multicolumn{1}{|c}{ valve } & length & height & width & elongation & obesity \\
\hline GP/1T 1980 & $\mathrm{R}$ & 50 & 38 & 30 & 1.31 & 1.26 \\
$\mathrm{GP} / 1 \mathrm{~T} 1978$ & $\mathrm{R} / \mathrm{L}$ & 45 & 32 & 24 & 1.40 & 1.33 \\
$\mathrm{GP} / 1 \mathrm{~T} 1981$ & $\mathrm{R}$ & 44 & 34 & 24 & 1.29 & 1.41 \\
$\mathrm{GP} / 1 \mathrm{~T} 2220$ & $\mathrm{R}$ & 40 & 34 & 18 & 1.17 & 1.88 \\
\hline
\end{tabular}

inflated. Umbones elevated above hinge line; beaks orthogyrous to slightly prosogyrous. Postumbonal ridge broad, poorly defined. Anterodorsal margin short, continuous with anterior margin; ventral margin convex; posterior margin obliquely truncated, producing small respiratory margin. Lunule, escutcheon absent. Right hinge with large, triangular, cardinal pivotal tooth; small socket anterior to tooth. Anterior and posterior adductor muscle scars well-marked; anterior muscle scar subcircular, bordered posteriorly by weakly developed buttress; posterior adductor scar circular; anterior retractor muscle scars small, connected to adductor muscle scar. Well developed umbonal elevator muscle scar on extremity of beak. Pallial line not observed.

Discussion. Newell \& Boyd (1975: 118) described the diagnostic features of $S$. ulrichi which include markedly anterior beaks, umbonal flanks not sharply differentiated, respiratory margin approximately half the height of shell, posterior ridge commonly broad and poorly defined, anterior buttress weakly developed, and a posterior retractor scar that extends dorsally as a long narrow slit, deepest toward dorsal end. All these features are present in the material from Piauí Formation. No similar species of Schizodus has been described from Paleozoic rocks in South America.

Schizodus cf. wyomingensis Newell \& Boyd, 1975

(Figure 5, Table 5)

Material. Five internal molds of right valves and five internal molds of left valves. GP/1T 2002; DNPM 074, 195, 244, 267, 291, 581a; GP/1T 1999, 2000, 2001.

Locality and horizon. José de Freitas, Piauí State, Brazil; Piauí Formation, Mucambo dolostone.

Age. Middle Pennsylvanian (Morrowan, Atokan).

Description. Shell subtrigonal, inequilateral, elongated to very elongated, very compressed. Umbones low, not above hinge line; beaks slightly prosogyrous, one-third length behind anterior extremity. Postumbonal ridge poorly defined. Anterodorsal margin short, anterior margin subcircular, ventral margin slightly convex; posterior extremity weakly truncated, with large respiratory margin; posterodorsal margin straight, short. Hinge short; pivotal tooth of left valve welldeveloped, triangular; small elongated tooth anterior to large socket. External features unknown. Adductor muscle scars well marked, nearly isomyarian, anterior scar subcircular, very close to anterior dorsal margin; posterior scar obliquely elongated; anterior, posterior pedal retractors nearly circular, 
immediately above adductors; anterior retractor partially connected to adductor; posterior retractor separate from adductor. Thick umbonal elevator on extremity of beak; pallial line thick, well marked, posteriorly truncated bellow posterior adductor, forming shallow rudimentary pallial sinus.

Discussion. The Piauí Formation specimens have shell shape and a posteriorly truncated pallial line as in S. wyomingensis, However, Schizodus cf. wyomingensis is more obese, having well developed dentition, and a smaller respiratory margin, so we tentatively designated these specimens as $S$. cf. wyomingensis.

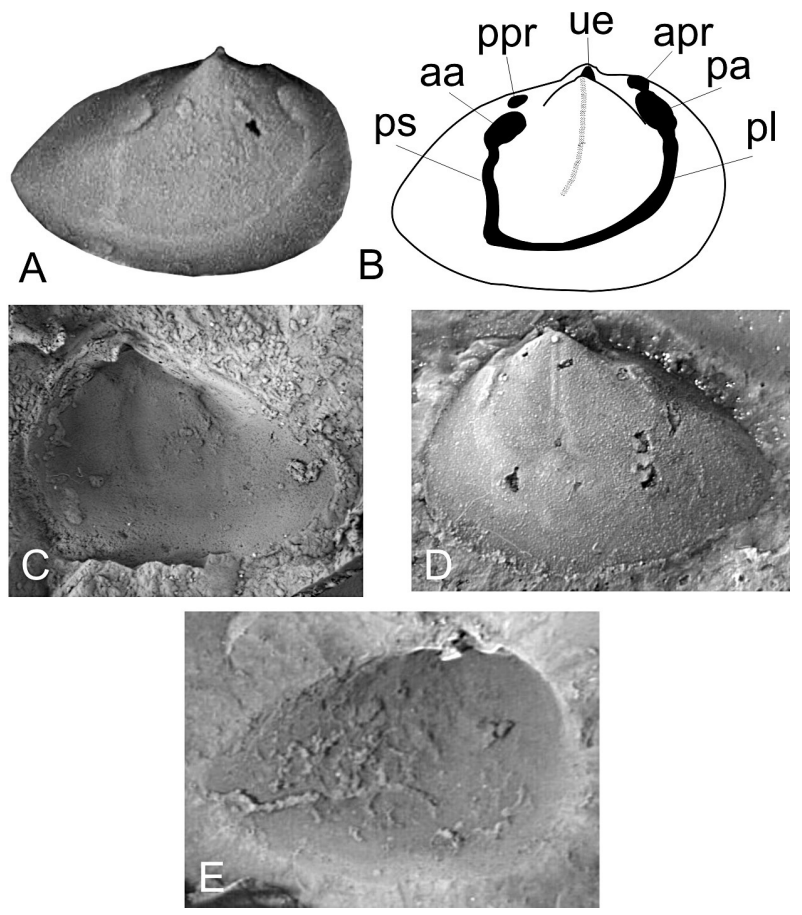

Figure 5. Schizodus cf. wyomingensis Newell \& Boyd, 1975, Mucambo dolostone: A, GP/1T 2002, internal mold of right valve showing muscle scars, $\times 3.5$; $\mathbf{B}$, muscle scars based on the same specimen, right valve view, x3.5; C, DNPM 244, latex cast, internal view of right side showing hinge features, x2.5; D, DNPM 195, internal mold of left valve, x3; E, GP/1T 1999, latex cast, internal view of left side showing hinge features, $x 2$.

Table 5. Measurements ( $\mathrm{mm}$ ) of Schizodus cf. wyomingensis. Asterisks indicate incomplete valves.

\begin{tabular}{l|cccccc} 
specimen & valve & length & height & width & elongation & obesity \\
\hline GP/1T 1999 & $\mathrm{L}$ & 13 & 9 & 5 & 1,4 & 1.8 \\
DNPM 244 & $\mathrm{R}$ & 14 & 8.1 & 3 & 1.72 & 2.7 \\
DNPM 195 & $\mathrm{L}$ & 12 & 7.1 & 2.6 & 1.69 & 1.9 \\
GP/1T 2002 & $\mathrm{R}$ & 10 & 7 & 4 & 1.42 & 1.75 \\
GP/1T 2001 & $\mathrm{L}$ & 12 & 7 & 4 & 1.71 & 1.7 \\
GP/1T 2000 & $\mathrm{R}$ & - & 7 & 3 & - & 2.3 \\
DNPM 074 & $\mathrm{R}$ & 10 & 6.2 & 2 & 1.61 & 3.1 \\
DNPM 581a & $\mathrm{R}$ & 10 & 6 & - & 1.66 & - \\
DNPM 291 & $\mathrm{L}$ & 9.1 & 6 & 3 & 1.52 & 2.0 \\
DNPM 267 & $\mathrm{L}$ & 8.5 & 5.1 & 2.2 & 1.67 & 2.3 \\
\hline
\end{tabular}

Superorder HETERODONTA Neumayr, 1883

Order VENEROIDA Adams \& Adams, 1856

Superfamily CRASSATELLOIDEA Férussac, 1822

Family ASTARTIDAE D`Orbigny, 1844

Subfamily ASTARTELLINAE Boyd \& Newell, 1968 Astartella Hall, 1858

Type-species. Astartella vera Hall, 1858.

Discussion. The material from Piauí Formation fits the diagnosis for the genus Astartella presented by Boyd \& Newell (1968: 45).

\section{Astartella subquadrata Lee \& Girty, 1909}

(Figures 6A-E, Table 6)

Material. Five internal molds of right valves, nine internal molds of left valves, and two external molds of left valves. DNPM 053, 163, 182, 258, 167, 273, 277a, 277b, 289; GP/1T 2004, 2005, 2006, 2007, 2008, 2009, 2031.

Locality and horizon. José de Freitas, Piauí State, Brazil; Piauí Formation, Mucambo dolostone.

Age. Middle Pennsylvanian (Morrowan, Atokan).

Description. Shell inequilateral, moderately elongate to elongate, moderately inflated. Umbones inflated, slightly elevated above hinge line; beaks strongly prosogyrous. Postumbonal ridge weakly distinct. Anterodorsal margin slightly concave; anterior margin produced; ventral margin convex with well defined crenulations on internal margin; posterior extremity truncated, defining short respiratory margin. Comarginal costae regularly spaced, numerous and well defined. Lunule short, escutcheon elongated, both narrow, well defined. Two cardinal teeth in each valve; anterior cardinal tooth 2 of left valve continuous to anterior lateral tooth AII; posterior cardinal tooth $4 \mathrm{~b}$ triangular, more pronounced than anterior; anterior lateral tooth AII of left valve well defined extending to end of anterior dorsal margin;

Table 6. Measurements $(\mathrm{mm})$ of Astartella subquadrata. Asterisks indicate incomplete valves.

\begin{tabular}{l|cccccc} 
specimen & valve & length & height & width & elongation & obesity \\
\hline DNPM 163 & $\mathrm{L}$ & 10.6 & 9 & 5 & 1.17 & 1.80 \\
DNPM 289 & $\mathrm{L}$ & $16^{*}$ & $16^{*}$ & - & - & - \\
DNPM 163 & $\mathrm{L}$ & 10.6 & 9 & 5 & 1.17 & 1.80 \\
DNPM167 & $\mathrm{L}$ & 7.5 & 5.5 & 4 & 1.36 & 1.37 \\
DNPM 277a & $\mathrm{R}$ & 7.5 & 5.5 & 3.6 & 1.36 & 1.52 \\
DNPM 182 & $\mathrm{R}$ & 7.1 & 5 & 2.6 & 1.42 & 1.92 \\
GP/1T 2009 & $\mathrm{L}$ & 7 & 5.6 & 3 & 1.35 & 1.86 \\
GP/1T 2008 & $\mathrm{L}$ & 7 & 5 & 4 & 1.40 & 1.25 \\
DNPM 053 & $\mathrm{R}$ & 6.9 & 5.4 & 3.6 & 1.27 & 1.50 \\
DNPM 277b & $\mathrm{L}$ & 6.8 & 5.5 & 3 & 1.24 & 1.83 \\
GP/1T 2006 & $\mathrm{R}$ & 6 & 4.2 & 2.2 & 1.42 & 1.90 \\
GP/1T 2004 & $\mathrm{R}$ & 6 & 4 & 2 & 1.50 & 2.00 \\
DNPM 273 & $\mathrm{L}$ & 6.5 & 4 & 2 & 1.37 & 2.00 \\
GP/1T 2007 & $\mathrm{L}$ & 5.2 & 3.6 & 2.4 & 1.44 & 1.50 \\
DNPM 258 & $\mathrm{L}$ & 3.9 & 2.4 & 1.8 & 1.63 & 1.33 \\
\hline
\end{tabular}


posterior lateral teeth PIV and PII of left valve well defined, with posterior end not reaching posterodorsal angle of respiratory margin. Anterior cardinal tooth $(3 b)$ of right valve straight, triangular in shape; posterior cardinal tooth $(5 b)$ of right valve vestigial; anterior lateral teeth $\mathrm{AI}$ and $\mathrm{AIII}$ running through anterodorsal margin, AI more pronounced; posterior lateral tooth PIII well defined. Nymph (n) above, posterior to cardinal tooth $4 \mathrm{~b}$ in left valve, virtually fused to dorsal margin of vestigial cardinal $5 \mathrm{~b}$ in right valve. Proposed hinge formula for A. subquadrata is as follows. See Boyd \& Newell (1968) for hinge formula notation:

$$
\begin{aligned}
& \text { RV PIII - } / \mathrm{n}(5 \mathrm{~b})-3 \mathrm{~b}-/ \mathrm{AI}-\mathrm{AIII} \\
& \text { LV PIV - PII /n - 4b - (2) /- AII }
\end{aligned}
$$

Adductor muscle scars isomyarian; anterior subcircular, strongly marked; posterior circular, weakly marked. Anterior, posterior pedal retractors scars well-marked, not fused to adductors. Distinct umbonal elevator present on extremity of beak. Pallial line integripalliate, faintly marked.

Discussion. Astartella subquadrata was first described from the Manzano Group of the New Mexico (Lee \& Girty, 1909) and later from the Permian Leonard Series (Clifton, 1942, not illustrated), Kaibab Formation (Chronic, 1952), Supai Formation (Winters, 1963) and Middle Rocks (Ciriacks, 1963). Ciriacks (1963) pointed out the similarities between $A$. subquadrata and $A$. nasuta Girty, 1908 and considered the possibility of the material being conspecific. A. nasuta was erected by Girty (1908) from the Guadalupian fauna and later recognized by Newell et al. (1953) from the Pennsylvanian of Peru; none of the material has internal features of the hinge preserved. It differs from A. subquadrata by the more pointed umbones and slightly greater respiratory margin.

Specimens of A. concentrica recognized from Pennsylvanian localities in the United States (Girty, 1915; Hoare et al., 1979) have a more pointed posterior end while $A$. subquadrata has a more pronounced truncated posterior end which gives the species the subquadrate shape. In addition, the hinge of A. concentrica illustrated by Hoare et al. (1979: 54) shows the cardinal teeth of the left valve of a different shape, and cardinal $3 \mathrm{~b}$ of the right valve more developed. It is noteworthy that $A$. subquadrata presents a double pattern of comarginal costae in different localities, being few and well developed in some cases (Lee \& Girty, 1909; Chronic, 1952) and numerous and slender in other cases (Winters, 1963). In the material from the Piauí, slender and numerous costae occur in specimens of small size, and the opposite for the larger specimens.

In South America, specimens assigned to Astartella have been recognized in the Pennsylvanian rocks of the Itaituba Formation (Mendes, 1966) and from the Caño Indio Formation (Benedetto, 1980a); however, the material is too poorly preserved for specific assignment.

\section{Astartella cf. concentrica (Conrad, 1842)}

(Figures 6F-J, Table 7)

Material. Two incomplete external molds of left valves, two internal molds of left valves and one internal mold of right valve. DNPM 068, 289; GP/1T 2221, 2032.
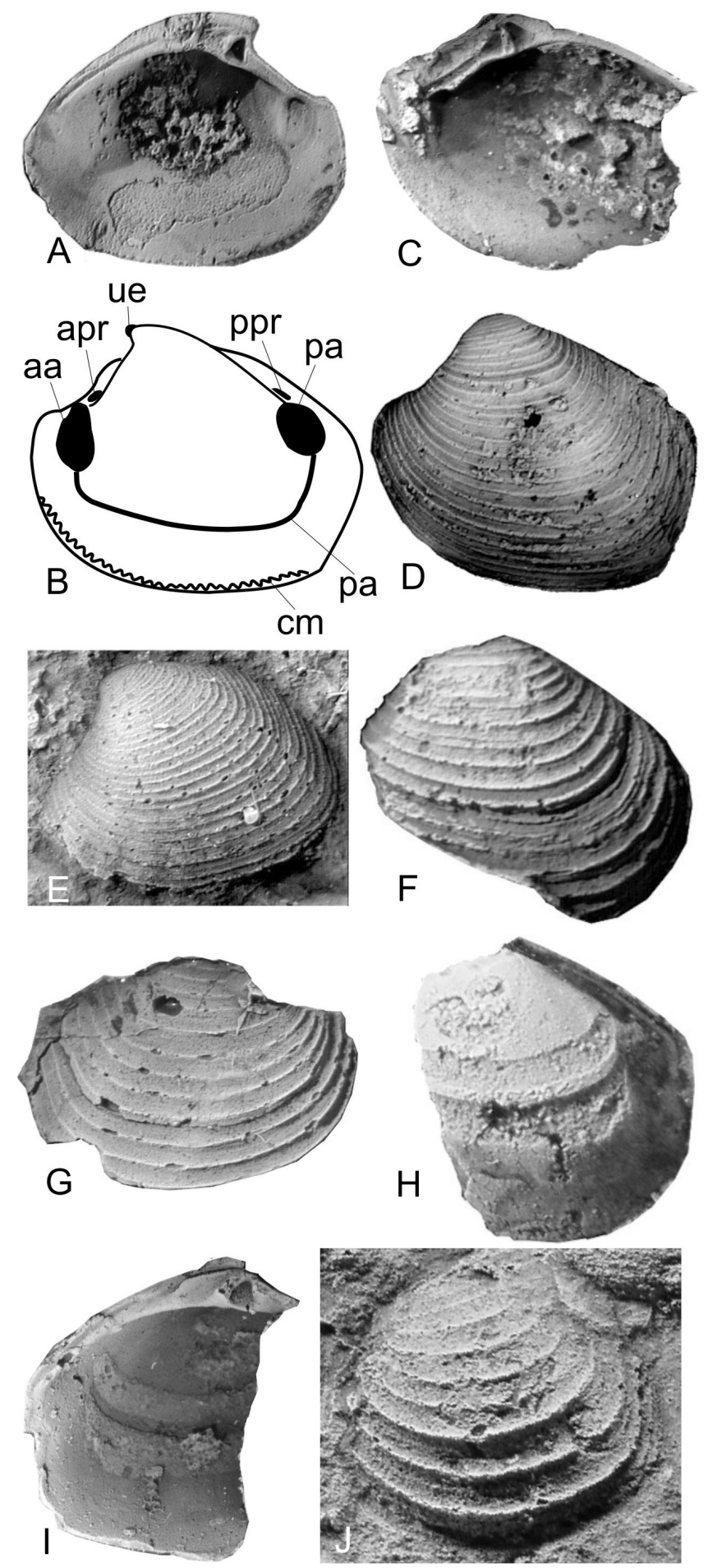

Figure 6. A-E, Astartella subquadrata Lee \& Girty, 1909, Mucambo dolostone: A, DNPM 163, latex cast, internal view of left side showing hinge features, $\times 3.5$; $\mathbf{B}$, muscle scars based in the same specimen, x3.5; C, DNPM 182, latex cast, internal view of a right side showing hinge features, x5; D, GP/1T 2031, latex cast, external view of a right side, x3.5; E, GP/1T 2004, latex cast, external view of left valve, small specimen, x6. F-J, Astartella cf. concentrica (Conrad, 1842), Mucambo dolostone: F, DNPM 068, latex cast, external view of fragmentary left valve, x3; G, GP/1T 2221, internal mold of left valve, x2.5; H, GP/1T 2032, internal mold of fragmentary left valve, x3; I, GP/1T 2032, latex cast, internal view of fragmentary left valve, x3; J, DNPM 289, latex cast, external view of left valve, $\mathrm{x} 2.5$. 
Table 7. Measurements (mm) of Astartella cf. concentrica. Asterisks indicate incomplete valves.

\begin{tabular}{l|cccccc} 
specimen & valve & length & height & width & elongation & obesity \\
\hline DNPM 289 & L & 18 & 16 & - & - & - \\
DNPM 068 & L & - & 12 & - & - & - \\
GP/1T 2221 & L & 14 & 11 & 4 & 1.27 & 1.37 \\
GP/1T 2032 & L & - & 11 & 4 & - & 1.37 \\
\hline
\end{tabular}

Locality and horizon. José de Freitas, Piauí State, Brazil; Piauí Formation, Mucambo dolostone.

Age. Middle Pennsylvanian (Morrowan, Atokan).

Description. Shell subcircular; inequilateral. Umbones inflated, not elevated above hinge line; beaks prosogyrous; umbonal ridge weakly marked, rounded. Postumbonal ridge rounded, poorly developed. Anterodorsal margin straight, short; anterior margin short; ventral margin convex, internal surface not crenulated; posterior margin truncated defining respiratory margin; posterodorsal margin slightly convex. Surface ornament of sharp, widely spaced, comarginal ridges. Two cardinal teeth in left valve; anterior cardinal tooth 2 continuous to anterior lateral tooth AII, slightly larger than posterior $4 \mathrm{~b}$, both triangular. Posterior lateral teeth PIV and PII well defined, posterior end of both reaching dorsal angle of respiratory margin. Large socket between cardinal teeth of left valve. Well defined triangular socket above cardinal tooth $4 \mathrm{~b}$ of left valve; very elongated slender nymph above tooth 4b. Cardinal teeth of right valve not observed.

Discussion. The external pattern of comarginal, well defined, and widely spaced ridges of $A$. cf. A. concentric suggests $A$. concentrica. A. concentrica was identified from rocks of Carboniferous age from Ohio (Hoare et al., 1979) and Oklahoma (Girty, 1915; Elias, 1957). However, the internal features of cardinal and lateral teeth were unreported in the North American species. No similar material has been described in South America.

Superorder ANOMALODESMATA Dall, 1899 Order PHOLADOMYOIDA Newell, 1965

Superfamily PHOLADOMYOIDEA (King, 1844) Gray, 1847 Family CHAEOMYIDAE Waterhouse, 1966 Chaenomya Meek, 1864

Type-species. Sanguinolaria gibbosa J. de C. Sowerby, 1827. Subsequent designation by Morris et al. (1991).

Comments. Chaenomya Meek, 1864, is similar to Gilbertsonia, but has a well developed posterior gape. This is present in the material of the Piauí Formation and for that reason those internal molds are referred here to Chaenomya.

Chaenomya caatingaensis $\mathrm{n}$. $\mathrm{sp}$. (Figure 7, Table 8)

Holotype. GP/1T 2019

Paratypes. DNPM 090, 103, 140, 223, 226, 230, 2006, 2007, 2008, 2018, GP/1T 2020, 2021, 2224.

Diagnosis. Chaenomya with concave dorsal margin, inflated, and posterior margin bearing a well marked, but small gap.

Material. Fourteen internal molds of conjugated valves.
Locality and horizon. José de Freitas, Piauí State, Brazil; Piauí Formation, Mucambo dolostone, unit 2.

Etymology. Caatingaensis, from Caatinga, the biome that characterizes the Piauí State.

Age. Middle Pennsylvanian.

Description. Shell very elongate, inflated, inequilateral, equivalve. Umbonal region inflated; umbonal carina absent. Beaks slightly prosogyrous, slightly above hinge line. Faint, large lateral sulcus from umbones to ventral margin.

Table 8. Measurements $(\mathrm{mm})$ of Chaenomya caatingaensis $\mathrm{n} . \mathrm{sp}$. Asterisks indicate incomplete valves.

\begin{tabular}{l|llllll} 
specimen & valve & length & height & width & elongation & obesity \\
\hline GP/1T 2019 & $\mathrm{R} / \mathrm{L}$ & 60 & 33 & 22 & 1.82 & 1.50 \\
DNPM 226 & $\mathrm{R} / \mathrm{L}$ & 57 & 29 & 20 & 1.96 & 1.45 \\
GP/1T 2020 & $\mathrm{R} / \mathrm{L}$ & 56 & 28 & 20 & 2.10 & 1.35 \\
DNPM 2007 & $\mathrm{R} / \mathrm{L}$ & 53 & 27 & 21 & 1.96 & 1.29 \\
DNPM 223 & $\mathrm{R} / \mathrm{L}$ & 50 & 30 & 21 & 1.67 & 1.43 \\
DNPM 2018 & $\mathrm{R} / \mathrm{L}$ & 50 & 27 & 19 & 1.85 & 1.42 \\
DNPM 230 & $\mathrm{R} / \mathrm{L}$ & 47 & 25 & 17 & 1.88 & 1.47 \\
DNPM 090 & $\mathrm{R} / \mathrm{L}$ & 47 & 25 & 18 & 1.88 & 1.39 \\
DNPM 2006 & $\mathrm{R} / \mathrm{L}$ & 45 & 23 & 16 & 1.96 & 1.44 \\
GP/1T 2224 & $\mathrm{R} / \mathrm{L}$ & 44 & 23 & 17 & 1.91 & 1,35 \\
DNPM 2008 & $\mathrm{R} / \mathrm{L}$ & 42 & 24 & 18 & 1.75 & 1.33 \\
GP/1T 2021 & $\mathrm{R} / \mathrm{L}$ & 41 & 23 & 17 & 1.78 & 1.35 \\
DNPM 140 & $\mathrm{R} / \mathrm{L}$ & 4 & 22 & 16 & 1.86 & 1.37 \\
DNPM 103 & $\mathrm{R} / \mathrm{L}$ & 30 & 19 & 14 & 1.57 & 1,35 \\
\hline
\end{tabular}

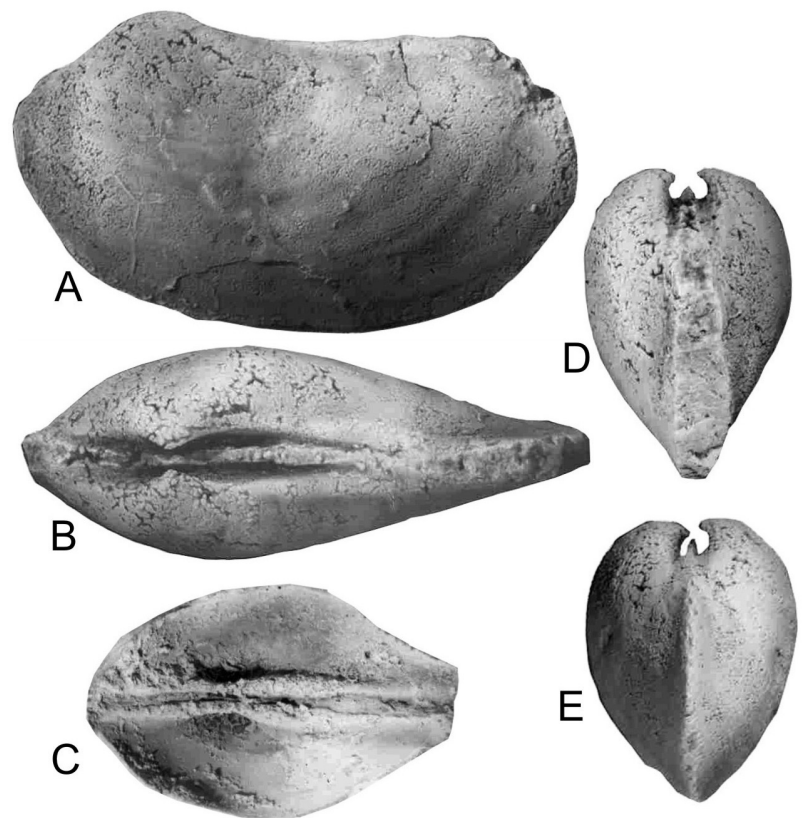

Figure 7. Chaenomya caatingaensis n. sp., Mucambo dolostone: A, GP/1T 2019, holotype, internal mold, left valve view, x1; B, dorsal view, same specimen, $\mathrm{x} 1$; C, partial latex cast of an internal mold showing hinge features, same specimen, x1; D, GP/1T 2035, paratype, internal mold, posterior view, x1; E, DNPM 2029, internal mold, anterior view, $\mathrm{x} 1$. 
Anterodorsal margin short; anterior margin nearly round; ventral margin convex; posterior margin dorsally inflected; posterodorsal margin slightly convex. Posterior siphonal gape narrow to mid width of shell; anterior extremity not gaping. Faint growth lines on relict shell; faint rugae irregularly spaced. Lunule distinct; escutcheon long, narrow. Hinge edentulous. Muscle scars unknown.

Discussion. No material similar to Chaenomya caatinguensis n. sp. has been described from North or South America. The main difference among $C$. caatinguensis and other species designated under Chaenomya is the presence in the former of a well developed siphonal gap.

\section{Family MEGADESMIDAE Vokes, 1967}

Comments. As pointed out by Runnegar \& Newell (1971) bivalves assigned to Megadesmidae Vokes, 1967, include robust and nacreous shells, with short siphons, a stout external ligament, lacking teeth or a blunt tooth in the right or both valves. However, Simões et al. (1997) performed a cladistic analysis on the monophyly of the Family Megadesmidae and found it supported only by the blunt tooth of the right valve.

The megadesmid from the Piauí has robust shells as inferred by the plaster casts which revealed a short and distinct nymph and a slightly blunt tooth in the right valve. These features suggest the following bivalves belong to the family Megadesmidae.

\section{Carnauba n. gen.}

Type-species. Carnauba oiticica $\mathrm{n}$. gen. and n. sp.

Diagnosis. Similar to Pyramus Dana, 1847 and Jacquesia Mendes, 1944, medium sized, stout shelled megadesmid, nearly oval in shape; right valve with one discrete but defined blunt tooth anterior to beak, resulting from a rising fold of the ventral margin of the hinge plate; immediately below the beak, a well marked depression separates the anterior blunt tooth from a possible small second tooth; externally, a discrete sharp to rounded carina runs from umbonal region to the posterior dorsal angle delimiting a respiratory margin. Vestigial punctae are poorly preserved in the posterior and anterior external regions of shell.

Etymology. Carnauba is a common tree in the semi-arid landscape of Piauí State.

Discussion. Carnauba n. gen. fits the majority of the generic characters listed by Runnegar (1967) for the genus Pyramus (Dana 1847), differing by its anteriorly directed beaks; the presence of a second small posterior tooth in the right valve separated from the anterior one by a large triangular alveolus for the left valve tooth; and one cardinal tooth in the left valve. Pyramus also has more pronounced muscle scars and an umbonal retractor at the apex of the umbonal cavity, characters absent in Carnauba n. gen. The well defined lateral sulcus found in Pyramus is also absent in Carnauba n. gen.. Jacquesia Mendes (1944) is another very similar megadesmid, with several features considered as diagnostic for the genus by Runnegar \& Newell (1971: 38) present also in Carnauba n. gen., but differing by its more elevated umbones, the very sharp posterior umbonal ridge, the sinuated ventral margin, and more strongly impressed muscle scars.

\section{Carnauba oiticica n. sp.}

(Figure 8, Table 9)

Holotype. DNPM 140a, 140b.

Paratypes. GP/1T 2222, DNPM 278.

Diagnosis. Same as for genus.

Etymology. Oiticica, a palm tree common in Piauí State.

Locality and horizon. José de Freitas, Piauí State, Brazil; Piauí Formation, Mucambo dolostone.

Age. Middle Pennsylvanian (Morrowan, Atokan).

Description. Shell nearly elliptical, thick, subequilateral, elongate, inflated. Umbonal region large, slightly elevated over hinge area; very short, shallow sulcus running ventrally;
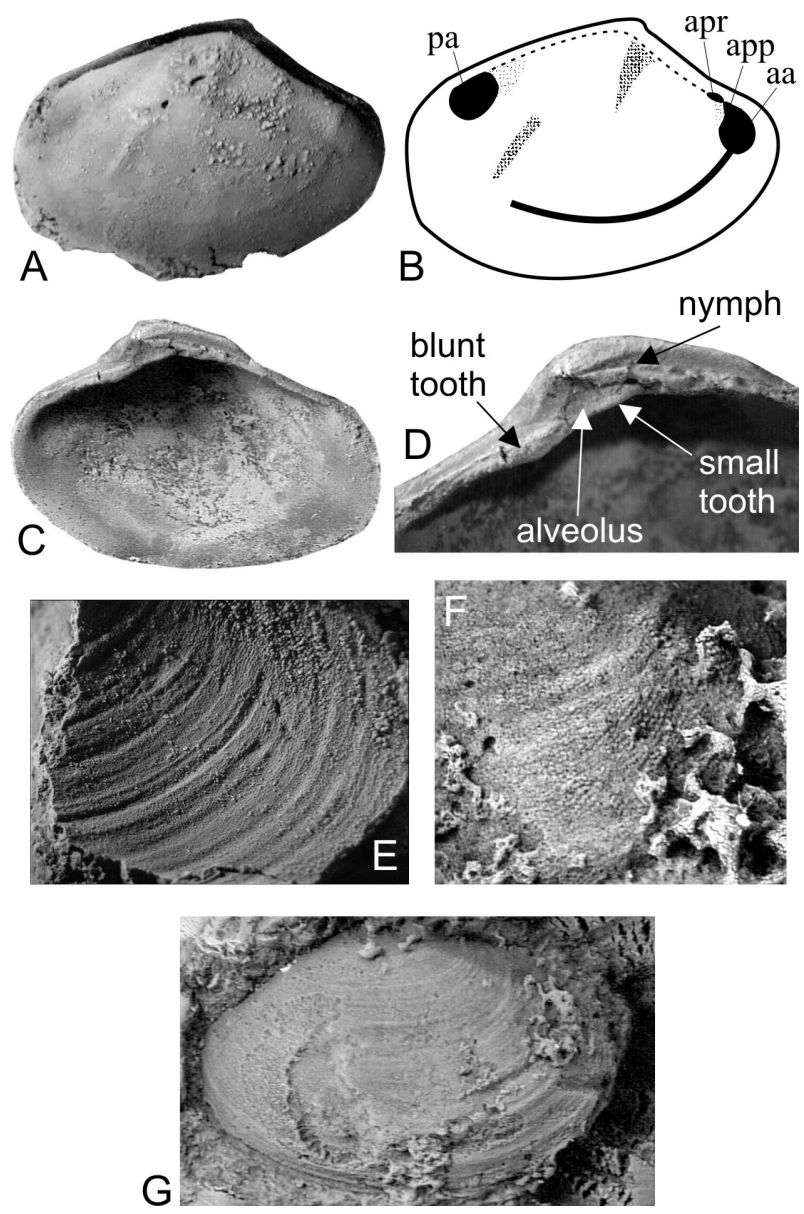

Figure 8. Carnauba oiticica n. gen. n. sp., Mucambo dolostone A, DNPM 140a, holotype, internal mold of right view, x1.5; B, muscle scars based on same specimen, $x 1.5$; C, latex cast, internal view of right side showing hinge features, same specimen; $\mathbf{D}$, latex cast, hinge area magnified, same specimen $\times 3$; E, DNPM 140b, paratype fragmentary external mold showing pattern of comarginal ornamentation, x3; F, GP/1T 2222, paratype, latex cast, magnification of posterior external surface of shell region showing reticulate pattern of ornamentation, $\mathrm{x} 6$; $\mathbf{G}$, latex cast, external mold, right valve view, x.1.5 
Table 9. Measurements (mm) of Carnauba oiticica n. gen., n. sp. Asterisks indicate incomplete valves.

\begin{tabular}{l|cccccc} 
specimen & valve & length & height & width & elongation & obesity \\
\hline GP/1T 2222 & $\mathrm{R}$ & $24^{*}$ & 16 & 8 & - & 2.00 \\
DNPM 140a & $\mathrm{R}$ & 22.5 & 15 & 8 & 1.50 & 1.87 \\
DNPM 278 & $\mathrm{R}$ & $19^{*}$ & 12 & 7 & - & 1.71 \\
DNPM 140 & $\mathrm{L}$ & 27 & 20 & 8 & 1.35 & 1.70 \\
\hline
\end{tabular}

posterior umbonal carina rounded, faintly marked; beaks prosogyrous. Anterior dorsal margin straight to weakly concave, anterior extremity rounded, ventral margin convex, posterior extremity truncated with well defined respiratory margin near half height; posterior dorsal margin straight. Lunule short, narrow; escutcheon narrow, long. Surface ornament of well-marked growth lines of varying width, irregularly spaced; puncta on posterior and anterior areas. The internal molds show a short and slender oblique elevation which may represent an interior depression in the shell immediately to posterior umbonal carina. Right valve hinge line with rotund anterior tooth; rotund, elongated posterior swelling, triangular depression, possibly alveolus for left valve tooth, between teeth under beaks. Adductor muscles scars anisomyarian. Anterior scar circular, at mid height, near anterior margin, with small scar, anterior pedal protractor, fused dorsally; faint anterior pedal retractor above adductor scar; posterior adductor slightly larger than anterior scar, subcircular, faint, near posterodorsal angle. Pallial line strong. Internal features of left valve unknown.

Discussion. Carnauba oiticica n. sp. is very similar to some Late Paleozoic specimens, regarded by Runnegar \& Newell (1974) as a questionable megadesmid (?Australomya, see Runnegar \& Newell, 1974: fig.10A-C). These are found in deposits of the Late Carboniferous and Permian Bone Springs Limestone of New Mexico, yielding a similar shell profile and muscle scars arrangement.

\section{Family SANGUINOLITIDAE Miller, 1877 Wilkingia Wilson, 1959}

Type-species. Venus elliptica Phillips, 1836.

Discussion. González (1997: 208) summarized the debate concerning related genera among the Sanguinolitidae; Wilkingia remains in a grouping of sanguinolitids with lunule and escutcheon, poorly developed umbonal ridge, and rows of small tubercles on the posterodorsal area. Morris et al. (1991) also included as diagnostic features "ribs constant in number, and a deep pallial sinus". Praeundulomya Dickins, 1957 differs from Wilkingia by its large size, subparallel dorsal and ventral margins, and a very slightly subumbonal sulcus.

\section{Wilkingia terminalis (Hall, 1852)}

(Figure 9, Table 10)

Material. 47 internal molds of left and right valves and five external molds: DNPM 45, 105, 133, 139, 214, 303; GP/1T 1997, 2010,2011, 2014, 2015, 2016, 2017, 2018, 2020, 2021, 2034, 2239,
2240, 2241.2240, 2241,2242, 2243, 2244, 2245, 2246, 2247, 2248, $2249,2250,2251,2252,2253,2254,2255,2256,2257,2258,2259$, 2260, 2261, 2262, 2263, 2264, 2265, 2266.

Locality and horizon. José de Freitas, Piauí State, Brazil; Piauí Formation, Mucambo dolostone.

Age. Middle Pennsylvanian.

Description. Shell strongly inequilateral, equivalve, very elongate. Senile shells strongly inflated; young specimens inflated to moderately inflated. Umbones subterminal; beaks slightly prosogyrous. Very shallow sinus broadens from umbo to gentle inflexion of ventral margin; postumbonal ridge very weak, rounded, extended to posterior extremity at low angle, near $20^{\circ}$ with dorsal margin. Anterodorsal margin straight, very short; anterior margin rounded; ventral margin weakly sinuous, weak flexion towards dorsal margin. Posterior extremity rounded, presenting posterior gape. Posterodorsal margin straight to slightly convex. Lunule well defined, deep, oval; escutcheon elongated, posterior larger, shallow. Surface ornament of sharp, regularly spaced, comarginal rugae on umbonal region, larger posteriorly with less developed groves. Hinge edentulous. Anterior adductor muscle scar well marked, circular, close to anterior extremity; well developed buttress from base of umbonal region to base of anterior adductor; posterior adductor muscle scar faintly marked, larger than anterior, transversely elongated, immediately behind mid length close to dorsal margin; small, elongated anterior pedal retractors above anterior adductors. Discussion. Wilkingia terminalis is very similar to $W$. regularis (King, in de Verneuil 1845, illustrated in Morris et al., 1991) from the Lower Carboniferous of Russia but differs by its more weakly marked comarginal rugae and the absence of radial striae. W. terminalis has been recognized from several Carboniferous and Permian localities in North America (Girty, 1903, from Colorado; Morningstar, 1922 and Hoare et al., 1979, from Ohio; Gordon \& Pojeta, 1975, from Wyoming, among others) and from the Carboniferous of South America

Table 10. Measurements $(\mathrm{mm})$ of Wilkingia terminalis. Asterisks indicate incomplete valves.

\begin{tabular}{l|cccccc} 
specimen & valve & length & height & width & elongation & obesity \\
\hline GP/1T 2020 & R/L & - & 46 & 12 & - & 1.24 \\
GP/1T 2021 & R/L & - & 45 & 10 & - & 1.15 \\
DNPM 214 & R/L & 104 & 43 & 9 & 2.42 & 1.19 \\
DNPM 133 & R/L & 103 & 41 & 9 & 2.51 & 1.21 \\
GP/1T 2016 & $\mathrm{R} / L$ & $99^{*}$ & 44 & 7 & 2.25 & 1.38 \\
GP/1T 2015 & $\mathrm{R} / \mathrm{L}$ & 99 & 41 & 8 & 2.41 & 1.32 \\
GP/1T 2017 & $\mathrm{R} / \mathrm{L}$ & 89 & 39 & 8 & 2.80 & 1.11 \\
GP/1T 2018 & $\mathrm{R} / \mathrm{L}$ & 82 & 35 & - & 2.34 & 1.21 \\
DNPM 105 & $\mathrm{R} / \mathrm{L}$ & 77 & 35 & 6 & 2.20 & 1.35 \\
DNPM 139 & $\mathrm{R} / \mathrm{L}$ & 74 & 34 & 7 & 2.18 & 1.36 \\
DNPM 45 & $\mathrm{R} / \mathrm{L}$ & 39 & 21 & 5 & 1.86 & 1.40 \\
GP/1T 2014 & $\mathrm{R}$ & 36 & 18 & 6 & 2.00 & - \\
GP/1T 2010 & $\mathrm{R} / \mathrm{L}$ & 25 & 12 & 3 & 2.08 & 1.50 \\
GP/1T 2011 & $\mathrm{R}$ & 17 & 12 & 3 & 2.08 & 1.50 \\
\hline
\end{tabular}



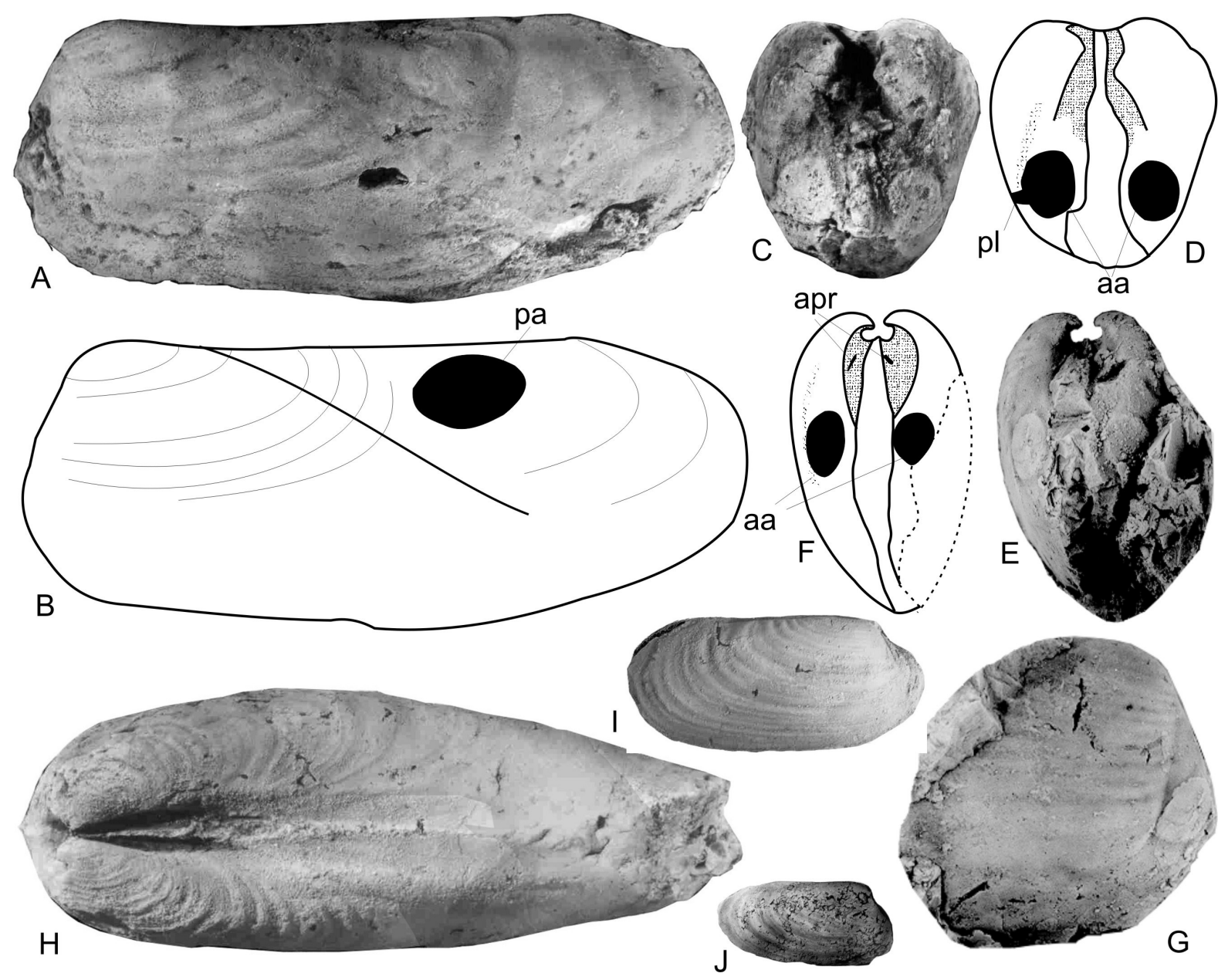

Figure 9. Wilkingia terminalis (Hall, 1852), Mucambo dolostone: A, DNPM 133, internal mold, left side view, x1; B, muscle scars based on the same specimen, x1; C, GP/1T 2012, anterior view of internal mold showing anterior adductors muscle scars, x1; D, muscle scars based on the same specimen, anterior view, x1; E, GP/1T 2013, fragmentary internal mold, anterior view, x1; F, muscle scars based in the same specimen, anterior view, x1; G, GP/1T 2013, fragmentary internal mold, anterior region, x1; H, DNPM 214, internal mold, dorsal view, $\mathrm{x} 1$; I, GP/1T 2034, internal mold of juvenile specimen, right valve view, x1; J, GP/1T 2010, internal mold, very small specimen, right valve view, $x 1$.

(Benedetto, 1980a, from Venezuela; González, 1992, 1997, from Argentina). W. riojana González, 1992 from the late Carboniferous rocks of western Argentina has more strongly marked comarginal rugae and is less elongated in shape. Wilkingia sp. was recognized by Mendes (1966) in the Pennsylvanian Itaituba Formation and is probably conspecific with $W$. terminalis from the Piauí.

\section{Sanguinolites M`Coy, 1844}

Type-species. Sanguinolites discors M'Coy 1844. Subsequent designation by Stoliczka (1871).

Comments. Differing from Sphenotus Hall (1858), Sanguinolites M'Coy, 1844 has a rugose comarginal ornament present anterior to the postero-umbonal ridge, absence of radial ornament posterior to the umbonal ridge (Pojeta et al., 1986; González, 1992, 1997), a curved ventral margin, and flank ornamented with distinct rounded ribs separated by wider interspaces (Morris et al., 1991). A great number of species from North and South America and Europe have been assigned to Sanguinolites; those presenting the radial ornament posterior to the umbonal ridge (see Hind, 1900, S. oblongus; Hind, 1904, S. monensis) should probably be reassigned to the genus Sphenotus (Pojeta et al., 1986).

Sanguinolites sp. 1

(Figures 10A-B, Table 11)

Material. One internal mold of right valve and two internal molds of fragmented left valves. GP/1T 1993, 1998, DNPM 225 .

Locality and horizon. José de Freitas, Piauí State, Brazil; Piauí Formation, Mucambo dolostone.

Age. Middle Pennsylvanian.

Description. Internal mold trapezoidal in shape, very elongated, inflated. Beaks prosogyrous. Umbones barely above hinge line, one third length from anterior extremity; umbonal carina rounded, weakly marked, from umbones to inferior angle of respiratory margin. Anterodorsal margin weakly concave; anterior margin rounded, continuous with 
Table 11. Measurements $(\mathrm{mm})$ of Sanguinolites sp. 1. Asterisks indicate incomplete valves.

\begin{tabular}{|c|c|c|c|c|c|c|}
\hline specimen & valve & length & height & width & elongation & obesity \\
\hline DNPM 225 & L & - & 15 & 10 & - & 1.52 \\
\hline GP/1T 1993 & $\mathrm{R}$ & 22 & 12 & 8 & 1.84 & 1.33 \\
\hline GP/1T 1998 & L & $16^{*}$ & 10 & 8 & - & 1.25 \\
\hline
\end{tabular}

weakly convex ventral margin; posterior margin truncated, defining respiratory margin; posterodorsal margin straight. Surface ornament of irregularly spaced comarginal rugae; lunule narrow and shallow, escutcheon large and distinct. Muscle scars unknown. Hinge edentulous.

Discussion. Sanguinolites sp. 1 is similar to Sanguinolites aff. S. naiadiformis Winchell, 1870, recognized by Hoare (1993) from the Mississippian (Chesterian) of the Virginias. It differs from Sanguinolites? sp. described by Chronic (1952) from the Permian Kaibab Formation by the position of the umbones which are more pronounced above the hinge line, and by its less elongated shape.

In South America, S. peruvianus? Thomas, 1928 was recognized by Newell et al. (1953) from Permian rocks of Peru; it differs in being a more elongated species. Mendes (1966) described Sanguinolites? chronici, but the material is too poorly preserved for rigorous comparison. S. carinatus Benedetto (1980a) from the Pennsylvanian Caño Indio Formation of Venezuela differs from $S$. sp. 1 by the well defined and more curved posterior carina and its smaller umbonal angle.

Sanguinolites sp. 2

(Figures 10C-F, Table 12)

Material. Two internal molds of left and two of right valves. GP/1T 1995, DNPM 304, 177, 123

Locality and horizon. José de Freitas, Piauí State, Brazil; Piauí Formation, Mucambo and Contendas dolostones.

Age. Middle Pennsylvanian.

Description. Shell inequilateral, elongated to very elongated, strongly inflated. Anterodorsal margin short, slightly concave; anterior margin rounded; ventral margin slightly convex, posterior margin truncated, large respiratory margin; posterodorsal margin straight. Umbones inflated, strongly curved toward hinge line; beaks prosogyrous; umbonal carina, lunule well-defined; escutcheon narrow, weak. Hinge edentulous. Surface ornament of thin, very weakly indistinct comarginal growth rugae. Anterior adductor muscle scar small, close to anterior margin at mid height, faintly marked, larger near base. Posterior scars, pallial line unknown.

Discussion. Sanguinolites sp. 2 is very similar in general shape to S. interruptus Hind, 1900 from Carboniferous of England, and S. carinatus Benedetto, 1980 from Pennsylvanian Caño Indio Formation (Benedetto, 1980a).

\section{Exochorhynchus Meek \& Hayden, 1865}

Type-species. ?Allorisma altirostrata Meek \& Hayden, 1865 by original designation.
Table 12. Measurements ( $\mathrm{mm}$ ) of Sanguinolites sp. 2. Asterisks indicate incomplete valves.

\begin{tabular}{|c|c|c|c|c|c|c|}
\hline specimen & valve & length & height & $\begin{array}{c}\text { half } \\
\text { width }\end{array}$ & elongation & obesit \\
\hline DNPM 304 & $\mathrm{R}$ & $17^{\star}$ & $9^{*}$ & 4.5 & 1.88 & $1.0^{*}$ \\
\hline DNPM 177 & L & 16 & 10 & 4.5 & 1.6 & 1.11 \\
\hline DNPM 123 & L & 16 & 9 & 5 & 1.77 & 0.9 \\
\hline GP/1T 1995 & $\mathrm{R}$ & 11.5 & 7.5 & 3 & 1.53 & 1.25 \\
\hline
\end{tabular}

Discussion. Two species of Exochorhynchus are distinguished based on the diagnoses found in Cox et al. (in Moore \& Teichert, 1969: 831) and in Morris et al. (1991) and on the general rounded shape, distinct escutcheon, and the poorly developed lunule similar to Wilkingia but with terminal beaks. Runnegar \& Newell (1974) include in their diagnose for Allorisma King, 1844 features as "an elongate, coarsely rugose shell"; characters also observed in the material from the Piauí Formation. However, Runnegar \& Newell (1974) also included diagnostic characters for Allorisma "hinge plate and pedal musculature as in Edmondia de Koninck 1841, and a prominent buttress behind the anterior pedal muscle insertion area", features that are clearly absent in the specimens here studied. Morris et al. (1991: 58) later added "lack of a distinct lunule and escutcheon" as additional diagnostic characters for Allorisma.

Specimens from Pennsylvanian rocks of Peru similar to those collected from the Piauí Formation were assigned to the genus Allorisma by Newell et al. (1953: 158), but none of the diagnostic features related to muscle scars as in Edmondia or the characteristic buttress were observed, leaving the attribution in question. Allorisma barringtoni (Thomas, 1928) from Peru, however, shows a well developed lunule and escutcheon, and was reassigned to Exochorhynchus by Morris et al. (1991). Myofossa Waterhouse, 1969, has a similar ovoid shape and external ornament but is distinguished by a ligament furrow in the escutcheon which is absent $E$. buriti and $E$. sp.

\section{Exochorhynchus buriti n. sp.} (Figure 10G)

Holotype. GP/1T 1997, an internal mold of right valve.

Diagnosis. Exochorhynchus with surface ornament of sharply defined ridges narrower than interspaces, and with a postumbonal carina forming a great angle with the dorsal margin.

Locality and horizon. José de Freitas, Piauí State, Brazil; Piauí Formation, Mucambo dolostone.

Etymology. Buriti, one of the most common trees in the semiarid landscape in Piauí State.

Age. Middle Pennsylvanian.

Description. Internal mold subcircular, strongly inequilateral. Length of $45 \mathrm{~mm}$, height of $30 \mathrm{~mm}$, width of internal mold of $24 \mathrm{~mm}$. Strongly inflated (obesity index 1.5), moderately elongate posteriorly (elongation index 1,25). Umbones subterminal, elevated well above hinge line. Beaks slightly 
prosogyrous. Postumbonal carina very weak, rounded, extending to mid length, forming angle of near $45^{\circ}$ with dorsal margin. Anterodorsal margin very short; anterior margin rounded; ventral margin convex; posterior margin rounded; posterodorsal margin straight. Surface ornament of sharply defined ridges narrower than interspaces, regularly spaced. Hinge features and muscle scars unknown.

Discussion. This Piauí specimen differs from the specimens of E. barringtoni (Thomas, 1928) from Peru (Newell et al., 1953 ) by its general shape and the pattern of external ornament. Mendes (1966) recognized similar material from the Itaituba Formation but did not justify his assignment to Allorisma. Mendes' specimens differ from the material studied here by their more subquadrate shape, more depressed umbones, and external ornament of regular, but well spaced sharply defined ridges. "Allorisma" barringtoni described by Rocha-Campos (1969) from Permian rocks of Paraná Basin, Brazil, has more spaced comarginal rugae.

\section{Exochorhynchus sp. \\ (Figures 10H-I)}

Material. DNPM 223, an internal mold of conjugated valves Locality and horizon. José de Freitas, Piauí State, Brazil; Piauí Formation, Mucambo dolostone.

Age. Middle Pennsylvanian.

Description. Internal mold subcircular, strongly inequilateral, equivalve. Length of $28 \mathrm{~mm}$, height of $21 \mathrm{~mm}$, width of conjugated valves of $17 \mathrm{~mm}$. strongly inflated (obesity index 1.23), moderately elongate (elongation index 1.25). Umbones subterminal, slightly elevated above hinge line. Beaks slightly prosogyrous. Postumbonal carina very weak, rounded, extending to mid length. Anterodorsal margin very short; anterior margin rounded; ventral margin convex, posterior extremity not preserved. Posterior dorsal margin straight. Surface ornament of well defined, regularly spaced, comarginal rugae slightly wider than interspaces. Lunule poorly developed, escutcheon shallow, long and wide. Hinge edentulous. Muscle scars unknown.

Discussion. The preservation of the single specimen does not permit specific identification. ?Allorisma sp. described by Reed (1930) from Permian rocks of Paraná Basin, Brazil, is more elongated and the surface of the shell is covered with a few comarginal rugae. Otherwise, no similar species appears to have been reported from North or South America. A small specimen of "Allorisma" barringtoni Thomas described by Rocha-Campos (1969: pl. 3, fig. 5) from Permian rocks of Paraná Basin, Brazil, shows great similarity with Exochorhynchus sp. here described, but differs by its more weakly impressed and spaced comarginal costae.

\section{cf. ANOMALODESMATA indet. 1 (Figures 11A-C)}

Material. GP/1T 2037, an internal mold of conjugated valves. Locality and horizon. José de Freitas, Piauí State, Brazil; Piauí Formation, Esperança dolostone.
Age. Middle Pennsylvanian.

Description. Internal mold subrectangular, strongly inequilateral, equivalve. Length of $55 \mathrm{~mm}$, height of $44 \mathrm{~mm}$, width of internal mold of $26 \mathrm{~mm}$. Compressed (obesity index 1.88), very elongate (elongation index 1.12). Umbones subterminal, even with hinge line. Beaks not visible. Postumbonal carina absent. Anterodorsal margin very short; anterior margin rounded; ventral margin straight; posterior extremity with large gape. Posterodorsal margin straight. Surface ornament of irregularly spaced comarginal rugae,

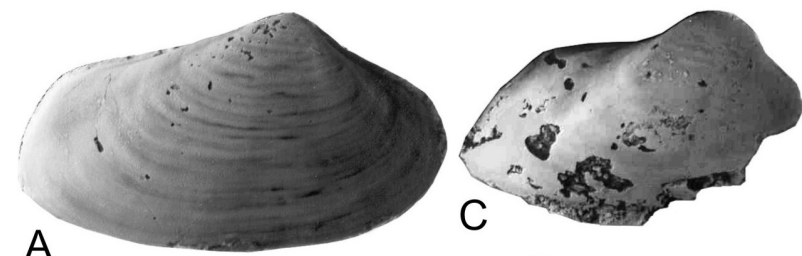

A
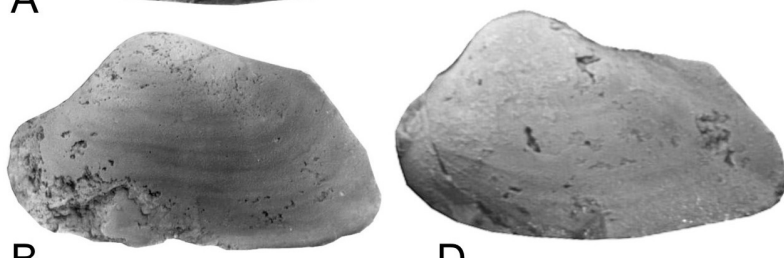

B
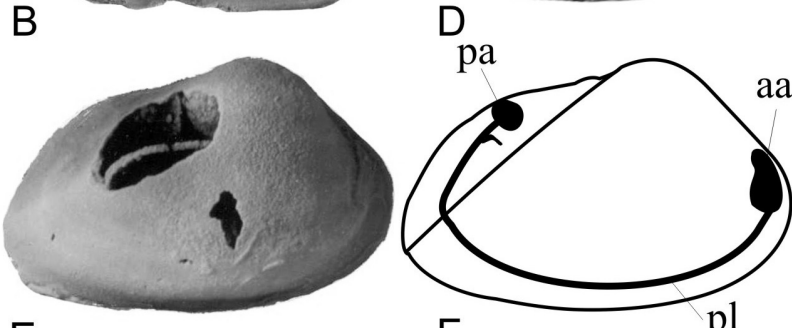

E

$\mathrm{F}$
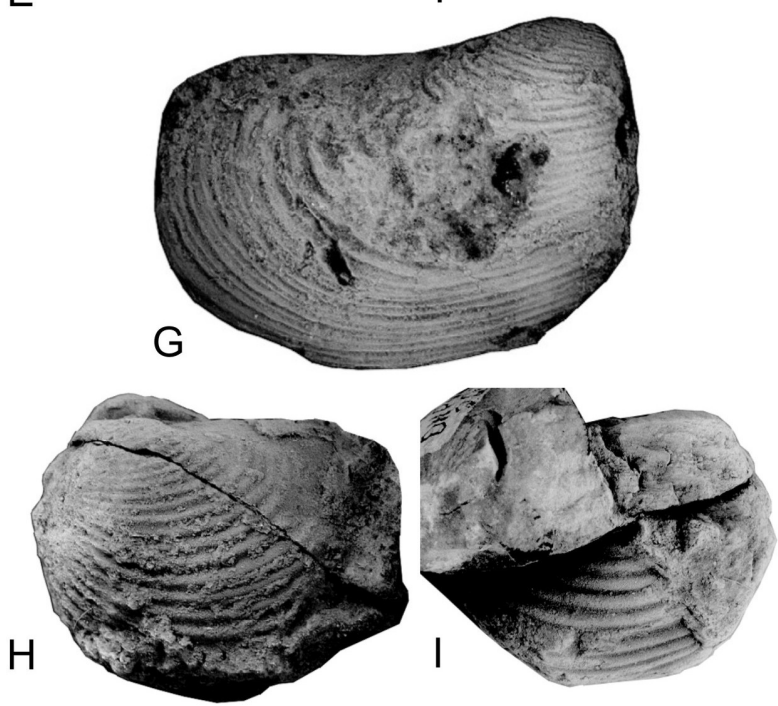

Figure 10. A-B, Sanguinolites sp. indet. 1, Mucambo dolostone: A, GP/1T 1993, internal mold, right view, x2; B, DNPM 225 , fragmentary internal mold, left view, x1.5. C-F, Sanguinolites sp indet. 2, Mucambo dolostone: C, DNPM 304, fragmentary internal mold, right view, x2; D, DNPM 177, internal mold, left view, x2.5; E, internal mold, right view, x3; F, GP/1T 1995, muscle scars based on specimen GP/1T 1995 left view, x3.5. G, GP/1T 1997, holotype, Exochorhynchus buriti n. sp., Mucambo dolostone, internal mold, right view x2. H-I, Exochorhynchus sp., Mucambo dolostone: H, DNPM 223, internal mold, left view, x2; I, same specimen, right view, $x 2$. 
posteriorly wider, more pronounced; few very faint radial rugae from postumbonal dorsal region; very faint numerous radiating ribs above ventral margin. Lunule, escutcheon absent . Hinge not visible. Anterior adductor muscle scar circular, at mid height near anterior margin; very faint buttress from base of umbonal region to base of anterior adductor. Elongated anterior pedal retractor scar in anterior dorsal margin nearly midway to beaks.

Discussion. Anomalodesmata indet. 1 has been compared to Anomalodesmata illustrated in Runnegar $(1966,1974)$ and Morris et al. (1991). Anomalodesmata indet. 1 shows no indication of structures related to an external ligament such as a nymph or an escutcheon as seen in all comparable members of Pholadomyacea (Pholadomya J. Sowerby, 1823; Chaenomya Meek, 1864; Homomya Agassiz, 1843; Osteomya Moesch, 1874; and Vacunella Waterhouse 1969). Also, all these genera differ from $A$. indet. 1 by their elongated shape and extended anterior portion, the presence of a well defined escutcheon, and a concave dorsal margin and convex ventral margin. Pholadomyoideans with a similar general shape and reduced anterior portion are Wilkingia, Praeundulomya, and Exochorhynchus, but all have well marked comarginal rugae, elongate shape, and well defined escutcheon.

\section{ANOMALODESMATA indet. 2}

(Figures 11D-E)

Material. GP/1T 2038, a fragment of an internal mold of left valve.

Locality and horizon. José de Freitas, Piauí State, Brazil; Piauí Formation, Meruóca dolostone.

Age. Middle Pennsylvanian.

Description. Shell inequilateral. Length of $62 \mathrm{~mm}$, height of $31 \mathrm{~mm}$, estimated width of internal mold of conjugated valves of $12 \mathrm{~mm}$. Very compressed (obesity index 2.6), very elongated (elongation index 2.0). Umbonal region not preserved; umbonal carina absent. Surface ornamented with irregularly spaced comarginal rugae. Adductor muscle scar large, circular, positioned above mid height, close to anterior extremity. Comments. The single specimen is poorly preserved and, therefore, difficult to compare.

\section{RESULTS}

\section{Faunal composition}

The fauna includes the following species of Heteroconchia: Pleurophorella parnaibaensis n. sp., Pleurophorella? sp., Schizodus alpinus (Hall, 1858), S. acuminatus Hoare, Sturgeon \& Kindt, 1978, S. ulrichi Worthen, 1890, S. mucamboensis n. sp., Astartella subquadrata, Lee \& Girty 1909, Astartella cf. concentrica (Conrad, 1842), Chaenomya caatingaensis n. sp., Carnauba oiticica n. gen. and sp., Wilkingia terminalis (Hall, 1852), Exochorhynchus buriti n. sp., Exochorhynchus sp.; Sanguinolites sp. 1, Sanguinolites sp. 2, Anomalodesmata indet. 1, and Anomalodesmata indet. 2. Among these, the species belonging to the permophorids (Pleurophorella parnaibaensis n. sp.), schizodonts (Schizodus alpinus, $S$. cf.
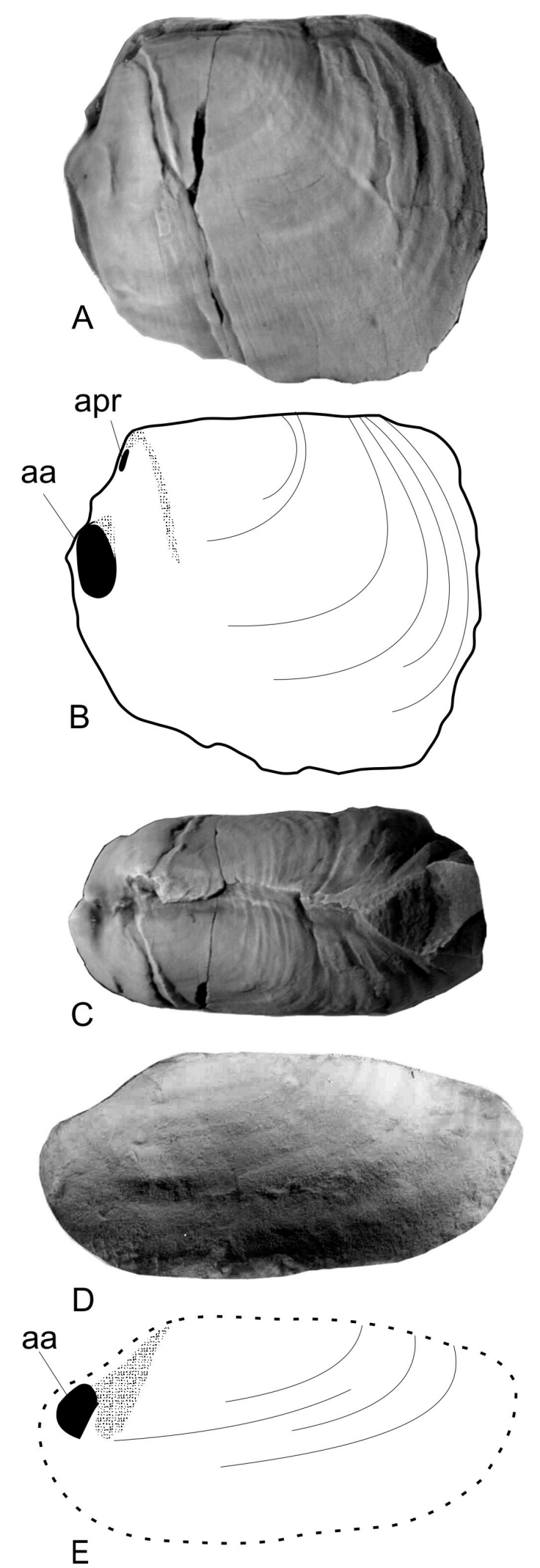

Figure 11. A-C, cf. Anomalodesmata indet. 1, Esperança dolostone: A, GP/1T 2037, internal mold of conjugated valves, left valve view, $\mathrm{x} 1$; $\mathbf{B}$, muscle scars based on same specimen, left valve view, $\mathrm{x} 1$; C, internal mold, dorsal view, same specimen $\times 1$. D-E, Anomalodesmata indet. 2, Meruóca dolostone: D, GP/1T 2038, fragmentary internal mold of left valve, $x 1 ; \mathbf{E}$, muscle scars based on same specimen, left valve view, $\mathrm{x} 1$. 
wyomingensis), astartellids (Astartella subquadrata), sanguinolitids (Wilkingia terminalis, Chaenomya caatingaensis $\mathrm{n}$. sp.), are by far the most abundant elements. On the other hand, Pleurophorella? sp., C. oiticica n. gen. and sp., Exochorhynchus buriti n. sp., and Exochorhynchus sp. are rare in the fauna.

\section{Taphonomy and paleoecology}

The Heteroconchia of the Piauí Formation are represented by semi-infaunal and infaunal suspension feeding bivalves. Heteroconchia, plus the associated macrofauna (including brachiopods, cephalopods, and trilobites) and microfauna (see Campanha \& Rocha-Campos, 1979) are all indicative of fully marine conditions. The assemblages found in the Mucambo dolostones (Figure 1) include several obrution beds (distal tempestites). In some of these event beds Heteroconchia bivalves (deep burrowing) are preserved in life position (see also Anelli et al., 1998). Members of the deep burrowing guild such as Chaenomya caatingaensis $\mathrm{n}$. sp. and Wilkingia terminalis, are commonly preserved with closed articulated valves, some in life position (see Anelli et $a l ., 1998$ ), with the long axis nearly perpendicular to bedding. The recurrent occurrence of these deep infaunal bivalves within pods of small bivalve-dominated shell debris indicates that the original muddy substrate was locally stabilized by minute bioclastic grains (Anelli et al., 1998), determining the preference of those species. Subsequently they were smothered in life by clouds of muddy sediment probably during storm events. Hence, these are autochthonous elements of the Mucambo dolostones. Shells of Pleurophorella parnaibaensis n. sp., a semi-infaunal bivalve, are also autochthonous to parautochthonous.

On the other hand, shells of some shallow burrowing bivalves, such as Schizodus alpinus and Schizodus cf. wyomingensis are found disarticulated and with signs (scars of tubes) of encrusting epibionts. Those specimens showing evidence of taphonomic feedback and were probably exposed in the sediment/water interface for some period of time, under low net sedimentation rates. Shells of these shallow infaunal species are parautochthonous to allochthonous (sensu Kidwell et al., 1996).

As shown by the examples above, in the studied dolostones bivalve shells belonging to distinct ecological guilds bear different taphonomic features. In other words, those shells had different taphonomic histories prior to final burial. These observations are suggestive that the studied bivalve assemblages yield high degrees of disharmonious time-averaging (see Simões \& Kowalewski, 1998), and that the paleoecology of the fauna must be viewed from this perspective.

All Heteroconchia, despite their mode of life, are preserved as internal and external molds. The molds of some deep infaunal species, such as Wilkingia and Chaenomya, when preserved in the original life position are sometimes compressed along the main axis of the shells.

\section{Faunal affinities}

The vast majority of bivalve genera and species described from the studied dolostones of the Parnaíba Basin (Anelli,
1999; Anelli et al., 2002, 2006) are also found in Pennsylvanian strata of North America. Among the Heteroconchia, for instance, six out of eight genera (Pleurophorella, Schizodus, Astartella, Wilkingia, Exochorhynchus, Sanguinolites) are common in faunas from the Pennsylvanian Pottsville and Allegheny groups of Ohio (Hoare et al., 1979). Yet, some of them are also present in rocks of the Pennsylvanian Amsden Formation of Wyoming (Gordon \& Pojeta, 1975) as well as in mid-Pennsylvanian beds of Missouri (Hoare, 1961). This relationship is rather remarkable, since the extensive Carboniferous Alleghenian orogeny, located between the two regions (Rast, 1984), is thought to have closed the migration route between Laurussia and the Gondwana portion of northern South America. In fact, the affinities of the Piauí fauna seem closer to the warm water Laurussian faunas than to coeval assemblages from Peru (Tarma Group and Cerro Prieto formation) and Venezuela (Caño Indio and Rio Palmar formations (Benedetto, 1980a,b), in northern South America, or cold water assemblages from the Paraná Basin of southern Brazil and Carboniferous basins from western Argentina (Rocha-Campos \& Archangelsky, 1985).

Heteroconch bivalves found in the invertebrate assemblages from the neighboring Amazon Basin (RochaCampos \& Archangelski, 1985) include the cosmopolitan genera Wilkingia, Sanguinolites, Astartella and Schizodus. These are also found in the Upper Carboniferous faunas from Argentina (Rocha-Campos \& Archangelsky, 1985; González, 1992, 1997).

\section{FINAL CONSIDERATIONS}

According to the present systematic description, at least 17 species, belonging to six families of the Heteroconchia are present in the studied material. Anomalodesmatans and Palaeoheterodonta are the most diversified and abundant groups, followed by heterodonts. The Piauí Formation fauna seems to include a mixture of endemic Gondwana element (megadesmid), plus cosmopolitan bivalves (Wilkingia, Astartella, Sanguinolites). The later genus also indicates affinities with Carboniferous marine faunas of the Itaituba Formation, Amazon Basin, and faunas from Pennsylvanian age of North America (Pottsville and Allegheny groups). Edmondiids, a cosmopolitan shallow burrowing bivalve common in Pennsylvanian strata of North America, were not found in the Piauí Formation yet.

Among the Anomalodesmatans, the presence of Megadesmidae suggests affinities with Late Paleozoic faunas of Australia and Argentina. Megadesmidae is a provincial group of infaunal bivalves that flourished in cool temperate seas, during the Carboniferous (Runnegar, 1967, 1972; Runnegar \& Newell, 1974). The presence of Megadesmidae in the studied dolostones indicates that this group thrived in warm water environments earlier in their history, since the Permian faunas of the Paraná (Passa Dois Group) and Karoo (Waterford Formation) basins are the unique in share a diverse Megadesmidae fauna (Runnegar \& Newell, 1971; Simões et al., 1997, 1998; Cooper \& Kensley, 1984) that lived in warm 
water conditions. The occurrence of a megadesmid in the Piauí Formation indicate that this group was not confined to cool temperate waters of the Gondwana supercontinent during the Carboniferous.

\section{ACKNOWLEDGMENTS}

We thank two anonymous reviewers for their suggestions and corrections that improved the final version of this paper. This research was supported by the following agencies: Conselho Nacional de Desenvolvimento Científico e Tecnológico (59969/92-3), and Fundação de Amparo à Pesquisa do Estado de São Paulo (1999/10797-4).

\section{REFERENCES}

Adams, H. \& Adams, A. 1853-58. The genera of Recent Mollusca. vol. 1, 1853-1854; vol. 2, 1854-1858; vol. 3, 1858, London.

Agassiz, L.J.R. 1842-1845. Eìtudes critiques sur les mollusques fossils. Monographie des Myes, $287 \mathrm{p}$.

Amler, M.R.W. 1999. Synoptical classification of fossil and Recent Bivalvia. Geologica et Palaeontologica, 33:237-248.

Anelli, L.E. 1999. Invertebrados neocarboníferos das formações Piauí (Bacia do Parnaíba) e Itaituba (Bacia do Amazonas): taxonomia; análise cladística das subfamílias Oriocrassatellinae (Crassatellacea, Bivalvia) e Neospiriferinae (Spiriferoidea, Brachiopoda). Programa de Pós-Graduação em Geologia Sedimentar, Universidade de São Paulo, Tese de Doutoramento, $184 \mathrm{p}$.

Anelli, L.E., Simões, M.G. \& Rocha-Campos, A.C. 1998. Mode of life of some Brazilian late Paleozoic Anomalodesmatans. In: P.A. Johnston \& J.W. Haggart (eds.) Bivalves: an Eon of evolution-paleobiological studies honoring Norman D. Newell. University of Calgary Press, p. 69-74.

Anelli, L.E., Rocha-Campos, A.C. \& Simões, M.G. 2002. Protobranch bivalves from the Piauí Formation (Middle Pennsylvanian), Parnaíba Basin, Brazil. Revista Española de Paleontología, 17:165-176.

Anelli, L.E.; Rocha-Campos, A.C. \& Simões, M.G. 2006. Pennsylvanian pteriomorphian bivalves from the Piauí Formation, Parnaíba Basin, Brazil. Journal of Paleontology, 80(6):1125-1141.

Benedetto, G.A. 1980a. Bivalvos pensilvanianos de la Formación Caño Indio, Sierra de Perijá, Venezuela. Boletín de Geología do Ministério de Energia y Minas, 14:197-245.

Benedetto, G.A. 1980b. Bioestratigrafia del Neopaleozoico de los Andes de Venezuela: una síntesis actualizada. Anais da Academia Brasileira de Ciências, 52(4):841-850.

Boyd, D.W. \& Newell, N.D. 1968. Hinge grades in the evolution of Crassatellacean bivalves as revealed by Permian genera. American Museum Novitates, 2328:1-52.

Brew, D.C. \& Beus, S.S. 1976. A middle Pennsylvanian fauna from the Naco Formation near Kohl Ranch, central Arizona. Journal of Paleontology, 50(5):888-906.

Busanus, J.W. \& Hoare, R.D. 1991. Bivalves (Mollusca) from the Much Chunk Group (Mississippian, Chesterian) of Northern West Virginia and southwestern Pennsylvania. Journal of Paleontology, 65(3):465-480.

Campanha, V.A. \& Rocha-Campos, A.C. 1979. Alguns microfósseis da Formação Piauí (Neocarbonífero), Bacia do Parnaíba. Boletim do Instituto de Geociências, 10:57-67.
Chavan, A. 1954. Les Pleurophorus et genres voisins. Cahiers Géologiques Seyssel, 22:1-200.

Chavan, A. 1969. Permophoridae. In: R.C. Moore (ed.) Treatise on Invertebrate Paleontology, Part N(2), Mollusca 6. Bivalvia. Geological Society of America and University of Kansas Press, p. 543-547.

Chronic, H. 1952. Molluscan fauna from the Permian Kaibab Formation, Walnut Canyon, Arizona. Bulletin of the Geological Society of America, 63(2):95-166.

Ciriacks, K.W. 1963 Permian and Eotriassic bivalves of the Middle Rockies. Bulletin of the American Museum of Natural History, 125:1-100.

Clifton, R.L. 1942. Invertebrate faunas from the Blaine and the Dog Creek Formations of the Permian Leonard Series. Journal of Paleontology, 16(6):685-699.

Conrad, T.A. 1842. Observations on the Silurian and Devonian Systems of the United States with descriptions of new organic remains. Philadelphia Academy of Natural Sciences Journal, 8:228-280.

Cooper, M.R. \& Kensley, B. 1984. Endemic South America Permian bivalve mollusks from the Ecca of South Africa. Journal of Paleontology, 58: 1360-1363.

Cox, L.R. et al.1969. Systematic Descriptions. In: R.C. Moore \& C. Teichert (eds.) 1969. Treatise on invertebrate paleontology, Part N, vol. 1-2, Mollusca 6: Bivalvia. Geological Society of America and University of Kansas Press, 952 p.

Dall, W.H. 1889. On the hinge of pelecypods and its development, with an attempt toward a better subdivision of the group. American Journal of Science, 38:445-462.

Dana, J.D. 1847. Descriptions of fossil shells of the Collections of the exploring expedition under the command of Charles Wilkers, U.S.N., obtained in Australia, from the lower layers of the coal formation in Illawarra, and from the deposit probably of nearly the same age at Harper's Hill, Valley of the Nunter. American Journal of Science, 54:151-160.

Dickins, J.M. 1957. Lower Permian pelecypods and gastropods from the Carnavon Basin. Western Australia. Bureau Mineral Resources, 55 p. (Bulletin 41).

Duarte, A. 1938. Fósseis carboníferos do Rio Jatapú. Serviço Geológico e Mineralógico, Departamento Nacional da Produção Mineral, 18 p. (Boletim 74).

Elias, M.K. 1957. Late Mississippian fauna from the Redoak Hollow Formation of Southern Oklahoma. Part 3. Pelecypoda. Journal of Paleontology, 31(4):737-784.

Feldmann, R.M.; Chapman, R.E. \& Hannibal, J.T. 1989 Paleotechniques. Paleontological Society Special Publication No 4, Knoxville, 358 p.

Férussac, A.E. 1822. Tableaux systématiques des animaux mollusques. Paris, $111 \mathrm{p}$.

Girty G.H. 1903. The Carboniferous formations and faunas of Colorado. United States Geological Survey, Professional Paper, 16:7-546.

Girty, G.H. 1904. New Molluscan genera from the Carboniferous. United States National Museum, Proceedings, 27(1372):721736.

Girty, G.H. 1908. The Guadalupean fauna. United States Geological Survey, Professional Paper, 58:1-651.

Girty, G.H. 1915. Fauna of the Wewoka Formation of Oklahoma. United States Geological Survey, 353 p. (Bulletin 544).

González, C.R. 1969. Nuevas especies de Bivalvia del Paleozoico superior del Sistema de Tepuel, Provincia de Chubut, Argentina. Ameghiniana, 6(3):236-250. 
González, C.R. 1992. Early Carboniferous Bivalvia from western Argentina. Alcheringa, 18:169-185.

González, C.R. 1997. Late Carboniferous Bivalvia from western Argentina. Geologica et Palaeontologica, 31:193-214.

Gordon Jr., M. \& Pojeta Jr., J. 1975. Pelecypoda and Rostroconchia of the Amsden Formation (Mississippian and Pennsylvanian) of Wyoming. United States Geological SurveyProfessional Paper, 848(E):1-24.

Gray, J.E. 1847. A list of the genera of recent Mollusca, their synonyms and Types. Zoological Society of London, Proceedings, 15:129-219.

Hall, J. 1852. Geology and paleontology. In: H. Stansbury (ed.), Exploration and survey of the valley of the Great Salt Lake of Utah, U.S. $32^{\text {nd }}$ Congress, Special Session, Senate Executive Document, p. 399-414.

Hall, J. 1858. Palaeontology of Iowa. Geological Survey of Iowa, Report, 1(2):473-727.

Herrick, C.L. 1887. A sketch of the geological history of Licking County, accompanying an illustrated catalogue of Carboniferous fossils from Flint Ridge, Ohio. Denison University Scientific Laboratories, 144-148 p. (Bulletin 2).

Hertwig, C.W.T.R. 1895. Lehrbuch der Zoologie. Gustav Fischer, Boulder, $599 \mathrm{p}$.

Hind, W. 1896-1905. A monograph of the British Carboniferous Lamellibranchiata. The Palaeontographical Society, London, 2 vol., 702 p.

Hoare, R. H. 1961, Desmoinesian Brachiopoda and Mollusca from southwest Missouri. University of Missouri Studies, 36, 262 p.

Hoare, R.D. 1993. Mississippian (Chesterian) bivalves from the Pennsylvanian stratotype area in West Virginia and Virginia. Journal of Paleontology, 67(3):374-396.

Hoare, R.D.; Heaney III, M.J. \& Mapes, R.H. 1989. Bivalves (Mollusca) from the Imo Formation (Mississippian, Chesterian) of north-central Arkansas. Journal of Paleontology, 63(5):582-603.

Hoare, R.D.; Sturgeon, M.T. \& Kindt, E.A. 1978. New Pennsylvanian bivalves and occurrences of Pseudoconocardiun from Ohio and West Virginia. Journal of Paleontology, 52:10231036.

Hoare, R.D.; Sturgeon, M.T. \& Kindt, E.A. 1979. Pennsylvanian marine Bivalvia and Rostroconchia of Ohio. Ohio DNR, Division of Geological Survey, 77 p. (Bulletin 67).

Kegel, W. 1951. Sobre alguns trilobitas carboníferos do Piauí e do Amazonas. Departamento Nacional de Produção Mineral, Divisão de Geologia e Mineralogia, 38 p. (Boletim 135).

Kegel, W. \& Costa, M.T. 1952. Espécies neopaleozóicas do Brasil da família Aviculopectinidae, ornamentada com costelas fasciculadas. Departamento Nacional de Produção Mineral, Divisão de Geologia e Mineralogia, 48 p. (Boletim 137)

Kidwell, S.M.; Fürsich, F.T. \& Aigner, T. 1986. Conceptual framework for the analysis and classification of fossil concentrations. Palaios 1(1):228-238.

King, W. 1844. On a new genus of paleozoic shells. Annals and Magazine of Natural History, 1(14):313-317.

Koninck, L.G. 1841-1844. Déscription des animaux fósiles qui se trouvent dans le terrain carbonifère de Belgique. Liège, $650 \mathrm{p}$.

Lamarck, J.B. de 1818-1819. Histoire naturelle des animaux sans vertèbres, $343 \mathrm{p}$.

Lee, W.T. \& Girty, G.H. 1909. The Manzano Group of the Rio Grande Valley, New Mexico. United States Geological Survey, 137 p. (Bulletin 389).
Lima Filho, F.P. 1991. Facies e ambientes deposicionais da Formação Piauí (Pensilvaniano), Bacia do Parnaíba, Brasil. Programa de Pós-Graduação em Geologia Sedimentar, Universidade de São Paulo, Dissertação de Mestrado, 137 p.

Lima Filho, F.P. 1999. A seqüência Permo-Pensilvaniana da Bacia do Parnaíba. Programa de Pós-Graduação em Geologia Sedimentar, Universidade de São Paulo, Tese de Doutoramento, $155 \mathrm{p}$.

Logan, A. 1967. The Permian Bivalvia of northern England. The Palaeontographical Society Monographs, 121(518):1-72.

Marwick, J. 1953. Divisions and faunas of the Hokonui system (Triassic and Jurassic). New Zealand Geological Survey Paleontological Bulletin, 141 p. (Bulletin 21).

M'Coy, F. 1844. A synopsis of the characters of the Carboniferous limestone fossils of Ireland. Printed at the University Press by M. H. Gill, Dublin, 207 p.

Meek, F.B. 1864. Check list of the invertebrate fossils of North America. Cretaceous and Jurassic. Smithsonian Miscellaneous Collection, 177(7):1-40.

Meek F.B. 1872. Preliminary paleontological report, consisting of lists of fossil, with descriptions of some new types. United States Geological Survey Wyoming, Preliminary Report, 1870:285-318.

Meek, F.B. 1875. A report on some of the invertebrate fossils of the Waverly Group and Coal Measures of Ohio. Ohio Geological Survey, 2 (2):269-347.

Meek, F.B. \& Hayden, F.V. 1865. Palaeontology of upper Missouri: Invertebrates. Smithsonian Contributions to Knowledge, 14(172):1-135.

Meek F.B. \& Worthen, A.H. 1860. Description of new Carboniferous fossils from Illinois and other western states. Philadelphia Academy of Natural Sciences Proceedings, 12:447-472.

Meek, F.B. \& Worthen, A.H. 1866. Descriptions of Paleozoic fossils from the Silurian, Devonian and Carboniferous rocks of Illinois and other western states. Chicago Academy of Sciences Proceedings, 1:11-23.

Mendes, J.C. 1944. Lamelibrânquios triássicos de Rio Claro (Estado de São Paulo). Faculdade de Filosofia, Ciências e Letras, Universidade de São Paulo, Geologia, 1:41-76. (Boletim 45).

Mendes, J.C. 1966. Moluscos da Formação Itaituba (Neocarbonífero) Estado do Pará, Brasil. Cadernos da Amazônia, 9:1-56.

Miller, S.A. 1877. The American Paleozoic Fossils: a catalogue of the genera and species. Cincinnati, $245 \mathrm{p}$.

Moesch, C. 1874-1875. Monographie der Pholadomyen. Abhandlungen Schweizerische Paläontologie Gesellschaft, 135 p.

Moore, R.C. \& Teichert, C. (eds.) 1969. Treatise on invertebrate paleontology, Part N, vol 1-2, Mollusca 6: Bivalvia. Geological Society of America and University of Kansas Press, 952 p.

Morningstar, H. 1922. Pottsville fauna of Ohio. Geological Survey of Ohio, Fourth Series, 312 p. (Bulletin 25).

Morris N.J.; Dickins, J.M. \& Astafieva-Urbaitis, K. 1991. Upper Paleozoic Anomalodesmatan Bivalvia. Bulletin of the British Museum of Natural History (Geology), 47(1):51-100.

Neumayr, M. 1883. Zur Morphologie des Bivalvenschlosses. Kaiserlich Königliche Akademie der Wissenschaften zui Wien. Naturwissenschaftlich-Mathematische Classe Sitzungsberichte, Abtheilung 1, 88(1):385-418.

Newell, N.D. 1965. Classification of the Bivalvia. American Museum Novitates, 2206:1-25.

Newell, N.D. 1969. Subclass Palaeoheterodonta. In: R.C. Moore \& C. Teichert (eds.) Treatise on Invertebrate Paleontology, Part 
N, vol. 1, Mollusca 6: Bivalvia. Geological Society of America and University of Kansas Press, p. N393-N489.

Newell, N.D. \& Boyd, D.W. 1975. Parallel evolution in early trigoniacean bivalves. Bulletin of the American Museum of Natural History, 154(2):1-162.

Newell, N.D. \& Boyd, D.W. 1999. A new Lower Triassic Permophorus from the Central Rocky Mountains. American Museum Novitates, 3263:1-5.

Newell, N.D.; Chronic, J. \& Roberts, T.C. 1953. Upper Paleozoic of Peru. Memoir of the Geological Society of America, 58:1-276.

Orbigny, A. d' 1844. Paléontologie française terrains crétacés, 3 , Mollusques, $870 \mathrm{p}$.

Phillips, J. 1836. Illustrations of the geology of Yorkshire, or a description of the strata and organic remains. Part 2.London, John Murray, 253 p., 24 pls., map.

Poel, Luc van de 1959. Faune malacologique du Hervien. Institut Royal des Sciences Naturelles de Belgique, p. 1-26 (Bulletin 35).

Pojeta, Jr., J.; Renjie, Z. \& Zunyi, Y. 1986. Systematic paleontology of the Devonian pelecypods of Guangxi and Michigan. United States Geological Survey, Professional Paper, 139(G):57-108.

Rast, N. 1984. The Alleghenian Orogeny in Eastern North America. Geological Society of America, Special Publication, 14:197-217.

Reed, F.R.C. 1930. Uma nova fauna Permo-Carbonífera do Brasil. Serviço Geológico e Mineralógico do Brasil, p. 1-45 (Monografia 10).

Rocha-Campos, A.C. 1969. Moluscos e braquiópodes eogondvânicos do Brasil e Argentina. Instituto de Geociências, Universidade de São Paulo, Tese de Livre Docência, 158 p.

Rocha-Campos, A.C. 1970. Moluscos permianos da Formação Rio Bonito (Subgrupo Guatá), SC. Departamento Nacional de Produção Mineral, Divisão de Geologia e Mineralogia, 89 p. (Boletim 251).

Rocha-Campos, A. C. \& Archangelsky S. 1985. South America. In: Wagner R.H., Winkler Prins, C.F. \& Granados, L.F. (eds.) The Carboniferous of the world II, Australia, Indian Subcontinent, South Africa, South America and North Africa, International Union of Geological Science Publication, 20:175-279.

Runnegar, B. 1966. Systematics and biology of some desmodont bivalves from the Australian Permian. Journal of the Geological Society of Australia, 13(2):373-386.

Runnegar, B. 1967. Desmodont bivalve from the Permian of eastern Australia. Bureau of Mineral Resources, Geology and Geophysics, 96 p. (Bulletin 99).

Runnegar, B. 1972. Anatomy of Pholadomya candida (Bivalvia) and the origin of the Pholadomyidae. Proceedings of the Malacological Society, London, 40:45-58.

Runnegar, B. 1974. Evolutionary history of the bivalve class Anomalodesmata. Journal of Paleontology, 48(5):904-939.

Runnegar, B. \& Newell, N.D. 1971. Caspian-like relict molluscan fauna in the South American Permian. Bulletin of the American Museum of Natural History, 149(1):1-62.

Runnegar, B. \& Newell, N.D. 1974. Edmondia and the Edmondiacea Shallow-Burrowing Paleozoic Pelecypods. American Museum Novitates, 2533:1-19.

Simões, M. G. \& Kowalewski, M. 1998. Shell beds as paleoecological puzzles: a case study from the Upper Permian of the Paraná Basin, Brazil. Facies, 38:175-196.

Simões, M.G.; Marques, A.C.; Mello, L.H.C. \& Anelli, L.E. 1997. Phylogenetic analysis of the genera of the extinct family
Megadesmidae (Bivalvia, Anomalodesmata), with remarks on its paleoecology and taxonomy. Journal of Comparative Biology, 2(2):75-90.

Simões, M.G.; Rocha-Campos, A.C. \& Anelli, L.E., 1998. Paleoecology and evolution of Permian pelecypod assemblages (Paraná Basin) from Brazil. In: P.A. Johnston \& J.W. Haggart (eds.) Bivalves: an Eon of evolution - paleobiological studies honoring Norman D. Newell. University of Calgary Press, p. 69-74.

Sowerby, J. de C. 1821-1822. The Mineral Conchology of Great Britain, vol. 4, p.1-114, London.

Sowerby, J. de C. 1823-1825. The Mineral Conchology of Great Britain, vol. 5, p.1-168, London.

Sowerby, J. de C. 1826-1829. The Mineral Conchology of Great Britain, vol. 6. p.1-230, London.

Stanley, S.M. 1970. Relation of shell form to life habits of the Bivalvia (Mollusca). Geological Society of America Memoir, 125:1-296.

Sterren, A.F. 2004. Bivalvos pérmicos de la Formación Tupe en la quebrada de La Herradura, provincial de San Juan. Ameghiniana, 41(1):57-74.

Sterren, A.F. 2005. Bivalvos carboníferos de la Formación La Capilla en el área de Las Cambachas, provincia de San Juan, Argentina. Ameghiniana, 42(1):209-219.

Stoliczka, F. 1870-1871. Cretaceous fauna of southern India III. The Pelecypoda, with a review of all known genera of this class, fossil and Recent. Geological Survey of India. Memoirs (Paleontologia Indica), 3:538.

Thomas, H.D. 1928. An Upper Carboniferous fauna from the Amotape Mountains, Peru. Geological Magazine, 65:146-300.

Verneuil, P.E.P. de 1845. Mollusques. In: R.I Murchinson; E. de Verneuil \& A. de Keyserling (eds.) Géologie de la Russie d'Europe, 2, 3, Paléontologie, p. 37-376.

Verneuil, P.E.P. de \& Murchison, R.I. 1844. Note sur les équivalents du système permien en Europe, suivie d'un coup d'oiel général sur l'ensemble de ses fossiles, et d'un tableau des espèces. Société Géologique de France, 505 p. (Bulletin 2).

Vokes, H.E. 1967. Genera of the Bivalvia: a systematic and bibliographic catalogue. Bulletin of the American Paleontologist, 51(232):111-393.

Waterhouse, J. B. 1966. On the validity of the Permian bivalve Family Pachydomidae Fisher, 1887. Journal of the Geological Society of Australia, 13:543-559.

Waterhouse, J.B. 1969. The Permian bivalve genera Myonia, Megadesmus, Vacunella and their allies, and their occurrence in New Zealand. New Zealand Geological Survey, 141 p. (Bulletin 41).

Wilson, R.B. 1959. Wilkingia gen. nov. to replace Allorisma for a genus of Upper Paleozoic lamellibranchs. Palaeontology, 1(4):401-404.

Winchell, A. 1870. Notices and descriptions of fossils from the Marshall Group of the western states, with notes on fossils from their formations. American Philosophical Society Proceedings, 11:245-60.

Winters, S.S. 1963. Supai Formation (Permian) of Eastern Arizona. Geological Society of America Memoir, 89:1-99.

Worthen, A.H. 1890. Description of fossil invertebrates. Illinois Geological Survey, 8:69-154.

Received in September, 2008; accepted in May, 2009. 